\title{
Targeting Mast Cells Tryptase in Tumor Microenvironment: A Potential Antiangiogenetic Strategy
}

\author{
Michele Ammendola, ${ }^{1}$ Christian Leporini, ${ }^{2}$ Ilaria Marech, ${ }^{3}$ \\ Cosmo Damiano Gadaleta, ${ }^{3}$ Giovanni Scognamillo, ${ }^{4}$ Rosario Sacco, ${ }^{1}$ Giuseppe Sammarco, ${ }^{1}$ \\ Giovambattista De Sarro, ${ }^{2}$ Emilio Russo, ${ }^{2}$ and Girolamo Ranieri ${ }^{3}$ \\ ${ }^{1}$ Department of Medical and Surgery Sciences, Clinical Surgery Unit, University "Magna Graecia” Medical School, \\ Viale Europa, Germaneto, 88100 Catanzaro, Italy \\ ${ }^{2}$ Department of Health Science, Clinical Pharmacology and Pharmacovigilance Unit and Pharmacovigilance's Centre Calabria Region, \\ University of Catanzaro "Magna Graecia" Medical School, Viale Europa, Germaneto, 88100 Catanzaro, Italy \\ ${ }^{3}$ Diagnostic and Interventional Radiology Unit with Integrated Section of Translational Medical Oncology, \\ Istituto Tumori “Giovanni Paolo II," Viale Orazio Flacco 65, 70124 Bari, Italy \\ ${ }^{4}$ Radiotherapy Unit, Istituto Tumori “Giovanni Paolo II,” Viale Orazio Flacco 65, 70124 Bari, Italy
}

Correspondence should be addressed to Girolamo Ranieri; giroran@tiscalinet.it

Received 13 February 2014; Revised 14 August 2014; Accepted 19 August 2014; Published 11 September 2014

Academic Editor: Xiaokun Li

Copyright @ 2014 Michele Ammendola et al. This is an open access article distributed under the Creative Commons Attribution License, which permits unrestricted use, distribution, and reproduction in any medium, provided the original work is properly cited.

Angiogenesis is a complex process finely regulated by the balance between angiogenesis stimulators and inhibitors. As a result of proangiogenic factors overexpression, it plays a crucial role in cancer development. Although initially mast cells (MCs) role has been defined in hypersensitivity reactions and in immunity, it has been discovered that MCs have a crucial interplay on the regulatory function between inflammatory and tumor cells through the release of classical proangiogenic factors (e.g., vascular endothelial growth factor) and nonclassical proangiogenic mediators granule-associated (mainly tryptase). In fact, in several animal and human malignancies, MCs density is highly correlated with tumor angiogenesis. In particular, tryptase, an agonist of the proteinase-activated receptor-2 (PAR-2), represents one of the most powerful angiogenic mediators released by human MCs after c-Kit receptor activation. This protease, acting on PAR-2 by its proteolytic activity, has angiogenic activity stimulating both human vascular endothelial and tumor cell proliferation in paracrine manner, helping tumor cell invasion and metastasis. Based on literature data it is shown that tryptase may represent a promising target in cancer treatment due to its proangiogenic activity. Here we focused on molecular mechanisms of three tryptase inhibitors (gabexate mesylate, nafamostat mesylate, and tranilast) in order to consider their prospective role in cancer therapy.

\section{Introduction}

Angiogenesis is a complex process, mainly mediated by endothelial cells, consisting in the formation of new blood capillaries from existing vessels [1-4]. It is finely regulated by the balance between several angiogenesis stimulators, such as vascular endothelial growth factor (VEGF), fibroblast growth factor-2 (FGF-2), platelet derived growth factor (PDGF), angiopoietins, tryptase, and some angiogenesis inhibitors, including thrombospondin, angiostatin, and endostatin [511]. Angiogenesis, further than being involved in normal physiological processes, has been demonstrated to play a crucial role in cancer development inducing tumor growth, invasion, and metastasis $[12,13]$.

Mast cells (MCs) intervene in tissue angiogenesis through several classical proangiogenic factors such as VEGF, FGF-2, PDGF, interleukin-6 (IL-6), and nonclassical proangiogenic factors, such as tryptase and chymase, stored in their secretory granules [14-18]. In fact, MCs density is highly correlated with the extent of tumor angiogenesis both in benign tumors (e.g., in keloids) and in animal and human malignancies (systemic mastocytosis, head and neck, colorectal, 
lung, and cutaneous cancer) [19-24]. Tryptase and chymase stimulate angiogenesis and the response is similar to that obtained with VEGF [16]. This evidence confirms even more the angiogenic activity of these two proteases stored in MCs granules [16].

\section{Role of Mast Cell Tryptase in Angiogenesis and Tumor Growth}

MCs are tissue leukocytes originating from hematopoietic stem cells in bone marrow. Generally, these precursor cells circulate in blood as agranular cells; then, MCs migrate into different tissues completing their maturation into granulated cells under the influence of several microenvironmental growth factors. One of these crucial factors is the stem cell factor (SCF), the ligand of c-Kit receptor (cKitR) secreted by fibroblasts and stromal and endothelial cells. SCF is critically involved in MCs activation $[25,26]$. MCs can be naturally found in association with connective tissue structures (i.e., blood vessels, lymphatic vessels, and nerves) and in the proximity of skin and mucosa of the gastrointestinal, respiratory, and genitourinary tracts [27], which represent common portals of infections [26, 28]. Accordingly, for many years, MCs have been implicated in the pathogenesis of IgE-associated allergic reactions and certain protective responses to parasites, bacteria, viruses, and fungi [29-31]. However, increasing evidence suggests the involvement of these cells in several biological settings, such as inflammation, immunomodulation, angiogenesis, wound healing, tissue remodeling, and cancer [17, 32-41]. Specifically, the multiple functions of MCs depend on their capability to release panoply of biologically active products upon suitable immunological and nonimmunological stimulation [42]. These mediators are either preformed in their secretory granules (biogenic amines, neutral serine proteases) or synthesized de novo (metabolites of arachidonic acid, cytokines) [43, 44]. MCs granules represent key functional elements, whose content can be released by two distinct secretory mechanisms: exocytosis (anaphylactic degranulation) or piecemeal degranulation [25]. Interestingly, the latter process is the most frequent secretory mechanism observed in chronic inflammatory settings, such as cancer $[31,45]$.

A possible causal relationship between MCs, chronic inflammation, and cancer has long been suggested. Accordingly, as most tumors contain inflammatory cell infiltrates, often including abundant MCs, the question about the possible contribution of MCs to tumor development has progressively been emerging $[31,39]$. MCs have been recognized as one of the earliest cell types to infiltrate many developing tumors, particularly malignant melanoma and breast and colorectal cancer (CRC) $[8,17,21,23,40,70,71]$. Ample evidence highlights that MCs accumulate predominantly around several types of tumors, at the boundary between malignant and healthy tissues $[8,17]$. In particular, these cells are often strategically located in proximity of blood vessels within the tumor microenvironment, suggesting an early role of MCs in angiogenesis and tumor growth; in fact angiogenesis generates a new vascular supply that delivers oxygen and nutrients to the rapidly proliferating malignant tissue $[25,39,72]$. In agreement with this role, MCs are an abundant source of potent proangiogenic factors, which represent a major issue linking these cells to cancer [26, 73]. In many experimental tumor settings, MCs promote angiogenesis by releasing preformed mediators or by activating proteolytic release of extracellular matrix-bound angiogenic molecules $[25,32,72]$. In vitro studies have demonstrated that MC granular components can induce vascularization [25]. Indeed, the addition of either human recombinant tryptase or chymase is able to stimulate neovascularization in the chick embryo chorioallantoic membrane assay (CAM) [32, 72]. Based on these results, treatment with cromolyn, an inhibitor of MCs degranulation, has been shown to restrain expansion and survival of pancreatic cancer and endothelial cells [15].

Tryptase and chymase are preformed active serine proteases and are stored in large amounts in MCs secretory granules [74], whose angiogenic role has been established $[16,75]$. In particular, tryptase represents one of the most powerful angiogenic mediators released by human MCs upon c-KitR activation, and it may be angiogenic via several mechanisms [24]. This protease directly stimulates human vascular endothelial cell proliferation acting on proteaseactivated receptor-2 (PAR-2) by its proteolytic activity [24, $75,76]$, leading to direct angiogenic effect (Figure 1). This particular proliferative pathway has been showed by Yoshii et al. [50] who have demonstrated that tryptase induces PAR2-mediated proliferative effects on a human colon carcinoma cell line (DLD-1 cells) in a mitogen-activated protein kinase (MAP) kinase- and cyclooxygenase- (COX-) dependent manner. PAR-2 activation also leads to the release of IL-6 and granulocyte-macrophage colony stimulating factor (GMCSF), which, in turn, act as angiogenic factors [77]. The important role of tryptase in neovascularization is also shown by its ability to degrade connective tissue matrix in order to provide rooms for neovascular growth. Tryptase may also contribute indirectly to tissue neovascularization by activating latent matrix-metalloproteinases (MMPs) and plasminogen activator, which, in turn, degrade extracellular matrix (ECM) with consequent release of ECM-bound angiogenic factors, such as VEGF and FGF-2 [25, 26, 52]. The disruption of local ECM leads also to release of SCF. Interestingly, tumor-derived SCF has been recently implicated both in MCs recruitment into the tumor environment as well as in increased MCs release and production of VEGF and FGF-2 $[78,79]$.

With reference to the above-described mechanisms that link tryptase to tumor angiogenesis and cancer progression, several studies have reported a linear correlation between mast cells density positive to tryptase (MCDPT) and angiogenesis in solid tumors, such as human malignant melanoma $[80,81]$, endometrial carcinoma [41], breast cancer $[8,82]$, uterine leiomyomas [83], gastric cancer [23, 24, 40], and CRC $[21,84]$. Regarding hematological tumors, angiogenesis has been shown to increase with the MCDPT in B cell nonHodgkin's lymphomas [85] as well as in the bone marrow of 


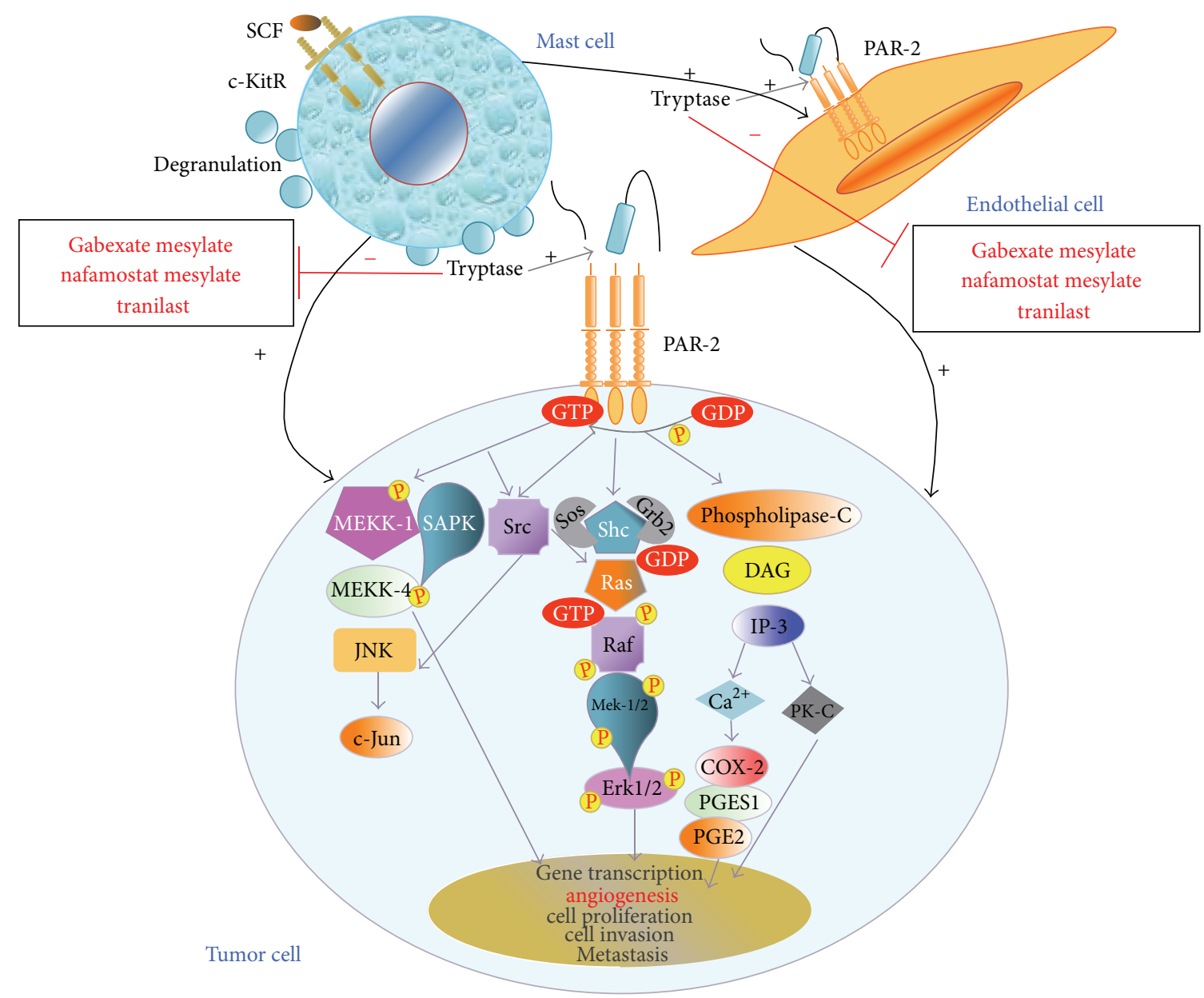

FIGURE 1: Tryptase, released after MCs activation of c-KitR/SCF-mediated, acting on PAR-2 by its proteolytic activity, has angiogenic activity stimulating both human vascular endothelial and tumor cell proliferation in paracrine manner, helping tumor cell invasion and metastasis. In cancer treatment, tryptase may represent a promising target by tryptase inhibitors (gabexate mesylate, nafamostat mesylate, tranilast) due to their potential antiangiogenic activity. c-KitR, c-Kit receptor; PAR-2, proteinase-activated receptor-2; VEGFR, vascular endothelial growth factor receptor; SCF, stem cell factor, VEGF, vascular endothelial growth factor; NHERF-1, Na+/H+ exchanger regulatory factor1; MEKK-1, mitogen-activated protein kinase/extracellular signal-related kinase-1; MEKK-4, mitogen-activated protein kinase/extracellular signal-related kinase-4; JNK, c-Jun N-terminal kinase; c-Jun, Jun protooncogene; SAPK, mitogen-activated protein kinase-9; GEF, rho/rac guanine nucleotide exchange factor; Rho, rhodopsin transcription termination factor; SOS, SOn of sevenless protein; Grb2, growth factor receptor-bound protein 2; Shc, Shc transforming protein kinase; Ras, Ras protein kinase; Raf, Raf protein kinase; mitogen-activated protein kinase/extracellular signal-related kinase-1/2; Erk, Elk-related tyrosine kinase; DAG, Diacylglycerol; IP-3, inositol triphosphate; PK-C, protein kinase-C; COX-2, cyclooxygenase-2; PGE2, prostaglandin E2; PGES-1, prostaglandin E synthase-1; PK-A, protein kinase-A.

patients with multiple myeloma, monoclonal gammopathies of undetermined significance [86], myelodysplastic syndrome [87], and B-cell chronic lymphocytic leukemia [85]. In the majority of studies, MCDPT correlates with angiogenesis, tumor aggressiveness, and poor prognosis [25], even if some human studies have demonstrated a correlation between high mast cells density (MCD) and improved overall survival [88-91], suggesting that MCs effects on tumor fate may depend on some bias related to cancer (e.g., type of surgical treatment with relative lymph node collection, histology, stage tumor, small sample size) and different methods of MCs evaluation (e.g., histochemistry with toluidine blue, Giemsa stain, primary antibody antitryptase or antichymase for immunohistochemistry, standardization of MCs count with reference to magnification, MCs location, and microscopic field of evaluation).

Overall, despite conflicting reports on the role of MCDand MCDPT-mediated angiogenesis in tumor development, literature data indicate that tryptase may represent a promising target in adjuvant cancer treatment $[25,26]$, leading to considering the therapeutic use of drugs which specifically inhibit its angiogenic activity. Therefore, tryptase inhibitors, such as gabexate mesylate and nafamostat mesylate [92-94], might be evaluated in clinical trials as new antiangiogenic agents in combination with chemotherapy in the treatment of cancer. 


\section{Potential Role of Mast Cells Tryptase Inhibitors in Cancer}

In the light of the aforementioned complex relationship between MCs tryptase and angiogenesis in tumor development, we have described the possible molecular mechanisms of three drugs targeting tryptase functions, such as gabexate mesylate, nafamostat mesylate, and tranilast, in order to discuss their prospective role in cancer therapy.

3.1. Gabexate Mesylate. Gabexate mesylate (GM) is a synthetic inhibitor of trypsin-like serine proteases [95-97] that shows an antiproteinase activity on various kinds of plasma proteases, such as thrombin, plasmin, trypsin, kallikrein, C1 esterase in the complement system, and factor Xa in the coagulation cascade. Accordingly, GM has been therapeutically used for disseminated intravascular coagulation (DIC) and acute pancreatitis [95] in Japan, Italy, Korea, and Taiwan. In addition, several recent studies have reported that this protease inhibitor exerts a significant antitumorigenic effect, both in vitro and in vivo $[46,47,94]$.

Proteolytic degradation of ECM components is a crucial step for tumor cell invasion and metastasis. Among several classes of degrading ECM proteinases, MMPs (MMP-2 and MMP-9) and urokinase-type plasminogen activator (uPA) have been closely associated with the metastatic phenotype of cancer cells [98-102]. These enzymes are also implicated in tumor angiogenesis [103]. Therefore, inhibitors of MMPs and UPA are able to inhibit invasion and metastasis [104, 105] by reducing angiogenesis in vitro and in vivo [106109]. Furthermore, serine plasma proteases, such as thrombin and plasmin, are closely associated with activation pathways of certain MMPs (MMP-2, MMP-3, and MMP-9) [110, 111], indicating that multispecific protease inhibitors could be useful tools for an antimetastatic and antiangiogenic strategy. Based on these findings, GM has been shown to inhibit proliferation, invasion, and metastasis of human colon cancer cell lines through the inhibition of both MMPs and uPAplasmin system, consequentially limiting angiogenesis [46]. Although the inhibition of the uPA system may be involved in downregulation of MMP activity, the results of this study have suggested that GM has a direct inhibitory effect on MMPs, whose related-mechanism is unknown [46].

Interestingly, the inhibition of MMPs by GM and, in general, its anti-invasive, antimetastatic, and antiangiogenic properties could also be explained through its potent and selective inhibition of human tryptase [92]. Indeed, as above described, in the early stages of tumor development several tumor-derived factors (i.e., SCF, adrenomedullin) recruit and activate MCs in tumor microenvironment, leading to the release of tryptase $[25,26]$, which, in turn, can indirectly stimulate tumor angiogenesis by activating latent MMPs and uPA [23, 24, 75]. Accordingly, Yoshii et al. [50] demonstrated the specific localization of MCDPT in the invasive front of tumor tissues by examining 30 cases of human colon adenocarcinoma. A previous study [49] has found the proliferation of DLD-1 colon cancer cells expressing PAR2 in response to PAR-2 activating peptide (AP). Moreover, tryptase also enhanced DLD-1 cell proliferation by means of a specific stimulation of PAR-2 via MAPK- and COXdependent manners. Furthermore, these proliferative effects were concentration-dependently inhibited by nafamostat mesylate, a very potent inhibitor of human tryptase [93, 112], suggesting that PAR-2 activation was dependent on tryptase proteolytic activity. In the same study, PAR-2 density in tumor tissues was higher than that in the normal tissues, as revealed by the immunohistochemical analysis. This suggests that tryptase released by MCs surrounding tumor tissues may induce the PAR-2-mediated proliferation of colon cancer cells in a paracrine way [49]. Similarly, tryptase has been reported to stimulate angiogenesis directly [75] via PAR-2 activation on vascular endothelial cells [24, 76]. Moreover, increasing evidences support that MCs tryptase is involved in angiogenesis through the direct degradation of connective tissue matrix $[25,26,75]$, with consequent release of matrixassociated angiogenic substances, such as VEGF or FGF$2[40,72,113-116]$. These findings as a whole suggest that MCs tryptase may sustain colon cancer cell growth in two ways: direct proliferative effect via PAR-2 stimulation and indirect support through angiogenesis stimulation. Thus, tryptase may be considered a novel target of colon cancer therapy. Taken together, all the reported evidences suggest that the inhibition of colon cancer growth, invasion, and metastasis by GM may be also due to its selective inhibition of MC tryptase. Therefore, GM could be potentially useful for antimetastatic and antiangiogenic treatment of colon cancers. Noteworthy, this assumption is corroborated by a recent study by Brandi et al. [47] aimed to investigate the antitumor efficacy of GM, alone, and in combination with the antiepidermal growth factor receptor (EGFR) monoclonal antibody cetuximab, in a group of human CRC cell lines with a different expression pattern of wild-type/mutated V-Ki-ras2 Kirsten rat sarcoma viral oncogene homolog (K-RAS), protooncogene B-Raf murine sarcoma viral oncogene homolog B1 (BRAF), and phosphatidylinositol-4,5-bisphosphate 3kinase, catalytic subunit alpha oncogene (PIK3CA). Besides confirming the lack of response to cetuximab in CRC cells bearing such mutations [117-119], results demonstrated that GM significantly inhibited the growth, invasiveness, and tumor-induced angiogenesis in all CRC cells tested in this study [47]. In particular, the antiangiogenic effect of GM in combination with the anti-EGFR antibody was found to be not superior than that observed with GM as single agent, suggesting that the inhibition of tumor angiogenesis may be largely related to GM mechanism of action, most notably the inhibition of MCs tryptase. Therefore, also considering its good toxicological profile, these findings indicate that GM could represent a valuable therapeutic option for patients with EGFR-expressing metastatic CRC (mCRC), particularly for those ones bearing KRAS, BRAF, and PIK3CA mutations, either as monotherapy or in combination with standard chemotherapy [47].

The antimetastatic and antiangiogenic mechanisms of GM have also been investigated in pancreatic cancer cell lines. As in colon cancer, MMPs and uPA play a crucial role also in the progression of pancreatic cancer [48]. In addition, a previous study by Uchima et al. [48] reported the involvement of tumor-associated trypsinogen (TAT) and 
TABLE 1: All preclinical studies mentioned above that have considered gabexate mesylate.

\begin{tabular}{|c|c|c|c|c|}
\hline $\begin{array}{l}\text { Author, reference, } \\
\text { year }\end{array}$ & Drug/s & Tumor target & Molecular mechanisms of action & Results \\
\hline Yoon et al. [46] 2004 & gabexate mesylate & $\begin{array}{l}\text { several human colon } \\
\text { cancer cell lines }\end{array}$ & $\begin{array}{l}\text { (1) down-regulation of MMPs } \\
\text { (2) inhibition of uPA-plasmin } \\
\text { system }\end{array}$ & $\begin{array}{l}\text { inhibition of angiogenesis, tumor } \\
\text { cell growth, invasion, metastasis }\end{array}$ \\
\hline Brandi et al. [47] 2012 & $\begin{array}{l}\text { (1) gabexate mesylate } \\
\text { (2) gabexate mesylate } \\
\text { plus cetuximab }\end{array}$ & $\begin{array}{l}\text { several human } \\
\text { colorectal cancer cell } \\
\text { lines (wt/mut KRAS, } \\
\text { BRAF, PIK3CA) }\end{array}$ & not analyzed & $\begin{array}{l}\text { (1) inhibition of tumor cell } \\
\text { growth, angiogenesis, invasion, } \\
\text { metastasis } \\
\text { (2) antitumoral efficacy of the } \\
\text { combination therapy was not } \\
\text { superior than gabexate mesylate } \\
\text { alone }\end{array}$ \\
\hline $\begin{array}{l}\text { Uchima et al. [48] } \\
2003\end{array}$ & gabexate mesylate & $\begin{array}{l}\text { several human } \\
\text { pancreatic cancer cell } \\
\text { lines }\end{array}$ & $\begin{array}{l}\text { down-regulation of uPA, TAT, } \\
\text { PAT, MMPs, TGF- } \beta 1, \text { VEGF }\end{array}$ & $\begin{array}{l}\text { inhibition of angiogenesis, cell } \\
\text { growth, invasion, metastasis }\end{array}$ \\
\hline
\end{tabular}

MMPs, Metalloproteinases; uPA, urokinase-type plasminogen activator; wt, wild-type; mut, mutated; TAT, Tumor-associated trypsinogen; PAT, Pancreatic acinar trypsinogen; TGF- $\beta 1$, Tumor growth factor-betal; VEGF, Vascular endothelial growth factor.

pancreatic acinar trypsinogen (PAT) in pancreatic cancer invasion and metastasis. Both these serine proteases can be activated by uPA, which is produced by pancreatic cancer. Following, they are able to degrade ECM components and can also directly activate TAT, PAT, pro-MMPs, and pro-uPA, leading to further ECM breakdown. The resulting vicious cycle would activate latent ECM-degrading proteases, thereby promoting tumor cell invasion and metastasis. In particular, PAT and TAT had been shown to continuously stimulate pancreatic cancer cell proliferation by activating PAR-2 [120]. Furthermore, several investigations reported that transforming growth factor-beta 1 (TGF- $\beta 1$ ), produced in the tumor microenvironment, could be a strong mediator of pancreatic cancer cell invasion, metastasis, and angiogenesis by upregulating VEGF, MMP-2, and uPA secretion [121-123]. High uPA levels, in turn, could activate latent TGF-betal, resulting in a positive feedback loop on tumor progression [123]. Starting from these data, Uchima et al. [94] suggested that GM inhibited the invasiveness, proliferation, and potential liver metastatic of pancreatic cancer cell lines by downregulating TAT and uPA activities, reducing PAR-2 activation, and inhibiting the production of TGF- $\beta 1$ and VEGF. Moreover, in pancreatic cancer the inhibitory effects of GM may be, in part, associated with tryptase inhibition. In fact, similarly to TAT, MCs tryptase may be responsible for PAR-2-mediated pancreatic cell proliferation, since tryptase is a natural agonist of this receptor [124]. Moreover, tryptase-mediated activation of latent MMPs and uPA $[25,26,75]$ may induce further TAT, MMPs, and UPA activation and ECM degradation, thus triggering an ECM-protease network responsible for tumor cell invasion and metastasis $[48,94]$. In this context, tryptase inhibition by GM may downregulate TAT and uPA enzymatic activities. The resulting downregulation of uPA levels may decrease the activation of latent TGF- $\beta 1$, thereby impairing the abovementioned cycle vicious of uPA and TGF$\beta 1$ and downregulating VEGF production. On the other hand, tryptase inhibition may also directly suppress the production of TGF- $\beta 1$ and VEGF involved in tumor growth and angiogenesis. In agreement with this proposed mechanism, tryptase has been reported to increase the production of TGF- $\beta 1$ in other pathophysiological settings $[125,126]$. The findings about the GM mechanism of action in pancreatic cancer cells, together with our considerations, indicate that this protease inhibitor could be a useful therapeutic option for antimetastatic and antiangiogenic treatment of pancreatic cancer.

The above studies are summarized in Table 1.

3.2. Nafamostat Mesylate. Similarly to GM, nafamostat mesylate (NM) is able to inhibit a variety of trypsin-like serine proteases and some proteases implicated in the coagulation cascade $[127,128]$. Interestingly, Mori et al. [93] have demonstrated that NM inhibits human tryptase with potency 1000 times higher than that of GM, concluding that NM is an extremely potent and selective inhibitor when employed at relatively low concentration. They have also suggested that such inhibitory action on tryptase activity can account for some therapeutic effects of NM in specific clinical conditions. Indeed, human tryptase may be involved in the pathogenesis of several MCs-mediated allergic and inflammatory diseases, such as rhinitis and asthma. It is also implicated in specific gastrointestinal, dermatological, and cardiovascular disorders [129-131]. Therefore, NM has been widely used for the treatment of acute pancreatitis and DIC in Japan [132, 133].

The antitumor potential of NM is suggested by Yoshii et al.s study previously described [50]. In fact, the in vitro analysis showed that NM concentration-dependently inhibited the tryptase-induced enhancement of proliferation of DLD-1 cells, thus suggesting that tryptase inhibition may mediate the anticancer effect of NM. It has also been reported that NM inhibits liver metastases of colon cancer cells in mice [134]. Moreover, previous studies showed that NM inhibited the proliferation and invasion of pancreatic cancer cells by antagonizing TAT-induced activation of PAR-2 in vitro, in the same fashion of GM [51,52]. Indeed, several studies have recently revealed that NM exerts antiproliferative, antiangiogenic, and antimetastatic effects also in pancreatic cancer, proposing the use of this serine protease inhibitor 
in combination with standard chemotherapy regimens for pancreatic cancer management [53-56]. In particular, the blockade of nuclear factor kappa-B (NF- $\kappa \mathrm{B})$ activation has been reported to underlie antitumor effects of NM [55]. In this regard, Karin and Lin have demonstrated that NF- $\kappa \mathrm{B}$ plays an important role in the modulation of inflammatory responses, cell proliferation, apoptosis, and oncogenesis including invasion and angiogenesis [55]. Typically, inactive $\mathrm{NF}-\kappa \mathrm{B}$ is sequestered in the cytoplasm by nuclear factor of kappa light polypeptide gene enhancer in B-cells inhibitor alpha $(\operatorname{IkB} \alpha)$; however, a specific activation signaling leads to $\operatorname{IkB} \alpha$ phosphorylation and consequent release of NF$\kappa \mathrm{B}$ protein, which translocates into the nucleus, where it induces the transcription of target genes [135]. Most notably, constitutive activation of NF- $\kappa \mathrm{B}$ has been identified in a variety of tumors including pancreatic cancer [135] and it is known to contribute to the aggressive phenotype [136] and chemoresistance [137]. The resulting overexpression of downstream target genes of NF- $\kappa \mathrm{B}$, such as intercellular adhesion molecule-1 (ICAM-1) [138], IL-8 [136, 139], VEGF [136, 139, 140], MMP-9 [140], and uPA [141], promotes cell adhesion, angiogenesis, invasion, and metastasis. Interestingly, some cancer chemotherapy drugs, such as oxaliplatin and gemcitabine, have been shown to activate NF- $\kappa$ B by themselves, thereby reducing their antitumor efficacy [142144]. Based on these findings, a NF- $\kappa$ B inhibitor like NM may be able to suppress proliferation, angiogenesis, and metastasis both in pancreatic cancer and in other malignancies, opening an avenue for novel therapeutic approaches. In the study by Fujiwara et al. [55], NM has been shown to downregulate activities of phosphorylated $\operatorname{IkB} \alpha, \mathrm{NF}-\kappa \mathrm{B}$, and its target genes, resulting in inhibition of cell adhesion, invasion, and increase of a particular programmed cell death (anoikis) in human pancreatic tumor cell lines. In vivo, intraperitoneal administration of pancreatic cancer cells, pretreated with $\mathrm{NM}$, in nude mice revealed reduced peritoneal metastasis and neovascularization and increased survival compared with controls. This suggests that NM may potentially reduce the incidence of postoperative recurrences due to peritoneal dissemination in pancreatic cancer patients [145]. In accordance with these findings, the authors have already reported the ability of NM to inhibit NF- $\kappa$ B activation and induce caspase8-mediated apoptosis when this serine protease inhibitor was used as monotherapy or with gemcitabine, in vitro and in vivo $[53,146,147]$. Most notably, they reported a better clinical outcome of combination therapy of gemcitabine or paclitaxel with NM in comparison with gemcitabine or paclitaxel alone in pancreatic cancer-bearing mice through the inhibition of chemotherapeutic drug-induced NF- $\kappa$ B activation $[53,55]$. It was also demonstrated the clinical usefulness of intra-arterial $\mathrm{NM}$ administration combined with gemcitabine in patients with unresectable pancreatic cancer [54, 148]. Accordingly, Gocho and colleagues [56] have recently proven that NM enhances the antitumor effect of oxaliplatin by inhibiting oxaliplatin-induced NF- $\kappa \mathrm{B}$ activation. This leads to downregulation of the cellular inhibitor of apoptosis proteins, $\mathrm{c}$ IAP1 and c-IAP2, resulting in cleavage of poly ADP-ribose polymerase (PARP) and caspase-8-mediated apoptosis in vitro and in vivo: the inhibition of NF- $\kappa \mathrm{B}$ activity results in chemosensitization of pancreatic cancer. Therefore, combination chemotherapy with $\mathrm{NM}$ and oxaliplatin exerts a synergistic cytotoxic effect in pancreatic cancer both in vitro and in vivo.

Taking into account the above-illustrated pathophysiological pathways, we propose that the potent inhibition of MCs tryptase may also be involved in the antitumor activities of NM. Firstly, this hypothesis is supported by the ability of tryptase to stimulate cell proliferation and invasion of cancer cells in vitro through the activation of PAR-2. We herein report the evidence of these tryptase-mediated proliferative effects only in colon cancer cells [50]; however, tryptase, being a natural agonist of PAR-2 [124], may be potentially able to activate this receptor class expressed also in the gastrointestinal tract, pancreas, liver, kidney, and sensory neurons [149151], triggering a proliferative response. Moreover, the above mentioned antiproliferative effect of NM in pancreatic cancer cells by blocking TAT-induced PAR-2 stimulation [51, 52] may be indirectly related to tryptase inhibition. In fact, we have previously reported that tryptase can activate the uPA system [25, 26, 75], which, in turn, activates TAT leading to stimulation of PAR-2 on the surface of pancreatic cancer cells [94]. On the other hand, the inhibition of tryptasemediated activation of PAR-2 on vascular endothelial cells could contribute to antiangiogenic effects of NM.

MCs tryptase may contribute to cancer pathways triggered by the constitutive activation of NF- $\kappa \mathrm{B}$. In particular, tryptase may upregulate the levels of several target genes overexpressed owing to the pathological NF- $\kappa \mathrm{B}$ activation, such as VEGF, IL-8, MMP-9, and UPA, thereby contributing to promote angiogenesis, invasion, and metastasis in a variety of tumors. Interestingly, several studies have reported that PAR-2 is able to mediate some important tryptaseinduced inflammatory processes, such as microglia activation and skin inflammation $[152,153]$. In particular, it has been shown that MC tryptase, via PAR-2, may induce the upregulation/release of proinflammatory cytokines (i.e., IL-6, IL-8, TNF- $\alpha$ ) and activate important inflammatory signaling cascades such as NF- $\kappa \mathrm{B}$ pathway in human dermal microvascular endothelial cells and microglia: MAPK signaling pathways are involved in NF- $\kappa \mathrm{B}$ activation and consequent production/release of proinflammatory cytokines by tryptase [152, 153]. Furthermore, according to Ma et al. [154] tryptase could phosphorylate protein-kinase $\mathrm{B}(\mathrm{PKB}$, also known as AKT) through PAR-2, activate phosphoinositol-3kinase $(\mathrm{PI} 3 \mathrm{~K}) / \mathrm{PKB}$ pathway, and upregulate the expression of $\mathrm{NF}-\kappa \mathrm{B}$ in inflammatory settings. Most notably, $\mathrm{PKB} / \mathrm{AKT}$ is involved in cellular survival pathways by inhibiting apoptotic processes [155]; hence, it has been implicated as a major factor in many types of cancers [156].

In the light of these last findings, MCs tryptase may probably contribute to the aggressive behavior and chemoresistance of pancreatic cancer cells, by activating NF- $\kappa \mathrm{B}$. Therefore, the inhibitory effect of $\mathrm{NM}$ on NF- $\kappa \mathrm{B}$ activities may also indirectly depend on the selective tryptase inhibition. On the other hand, tryptase inhibition could also justify the apoptotic effect of NM through the downregulation of $\mathrm{PI} 3 \mathrm{~K} /$ protein kinase $\mathrm{B}(\mathrm{PKB})$ signaling pathway. As a whole, the above detailed findings and mechanisms suggest 
TABLE 2: All studies mentioned above that have considered nafamostat mesylate.

\begin{tabular}{|c|c|c|c|c|}
\hline $\begin{array}{l}\text { Author, reference, } \\
\text { year }\end{array}$ & Drug/s & Tumor target & Molecular mechanisms of action & Results \\
\hline $\begin{array}{l}\text { Jikuhara et al. [49] } \\
2003\end{array}$ & $\begin{array}{l}\text { nafamostat } \\
\text { mesylate }\end{array}$ & $\begin{array}{l}\text { human colon cancer } \\
\text { cell line (DLD-1) }\end{array}$ & $\begin{array}{l}\text { (1) inhibition of PAR-2 } \\
\text { stimulation via MAPK- and } \\
\text { COX-dependent manner } \\
\text { (2) inhibition of VEGF and } \\
\text { FGF-2 levels }\end{array}$ & $\begin{array}{l}\text { inhibition of tumor cell growth, } \\
\text { angiogenesis, invasion, } \\
\text { metastasis }\end{array}$ \\
\hline Yoshii et al. [50] 2005 & $\begin{array}{l}\text { nafamostat } \\
\text { mesylate }\end{array}$ & $\begin{array}{l}\text { human colon cancer } \\
\text { cell line (DLD-1) }\end{array}$ & $\begin{array}{l}\text { (1) Inhibition of PAR-2 } \\
\text { stimulation via MAPK- and } \\
\text { COX-dependent manner } \\
\text { (2) Inhibition of the release of } \\
\text { IL-6 and GM-CSF }\end{array}$ & $\begin{array}{l}\text { inhibition of angiogenesis, cell } \\
\text { growth, invasion, metastasis }\end{array}$ \\
\hline Tajima et al. [51] 2001 & $\begin{array}{l}\text { nafamostat } \\
\text { mesylate }\end{array}$ & $\begin{array}{l}\text { several human } \\
\text { pancreatic cancer cell } \\
\text { lines }\end{array}$ & $\begin{array}{l}\text { antagonizing TAT-induced } \\
\text { activation of PAR-2 }\end{array}$ & $\begin{array}{l}\text { inhibition of tumor cell growth } \\
\text { and invasion }\end{array}$ \\
\hline Ohta et al. [52] 2003 & $\begin{array}{l}\text { nafamostat } \\
\text { mesylate }\end{array}$ & $\begin{array}{l}\text { several human } \\
\text { pancreatic cancer cell } \\
\text { lines }\end{array}$ & $\begin{array}{l}\text { antagonizing TAT-induced } \\
\text { activation of PAR-2 }\end{array}$ & $\begin{array}{l}\text { inhibition of tumor cell growth } \\
\text { and invasion }\end{array}$ \\
\hline $\begin{array}{l}\text { Uwagawa et al. [53] } \\
2009\end{array}$ & $\begin{array}{l}\text { (1) nafamostat } \\
\text { mesylate } \\
\text { (2) nafamostat } \\
\text { mesylate plus } \\
\text { gemcitabine }\end{array}$ & $\begin{array}{l}\text { human pancreatic } \\
\text { cancer cell line } \\
\text { (Panc-1) }\end{array}$ & $\begin{array}{l}\text { Down-regulation of NF- } \kappa \text { B with } \\
\text { reduction of ICAM-1, IL-8, } \\
\text { VEGF, MMP-9, uPA, RRM1 }\end{array}$ & $\begin{array}{l}\text { (1) inhibition of tumor cell } \\
\text { adhesion and growth, } \\
\text { angiogenesis, invasion metastasis } \\
\text { (2) increase of apoptosis } \\
\text { (3) increase of body weight loss } \\
\text { of mice }\end{array}$ \\
\hline $\begin{array}{l}\text { Uwagawa et al. [54] } \\
2009\end{array}$ & $\begin{array}{l}\text { nafamostat } \\
\text { mesylate plus } \\
\text { intra-arterial } \\
\text { gemcitabine }\end{array}$ & $\begin{array}{l}\text { unresectable locally } \\
\text { advanced or } \\
\text { metastatic pancreatic } \\
\text { cancer } \\
(20 \text { pts })\end{array}$ & not analyzed & $\begin{array}{l}\text { (1) CBR of } 60 \% \\
\text { (2) reduction of CA19-9 serum } \\
\text { level in } 90 \% \text { of pts } \\
\text { (3) improvement in } \\
\text { health-related quality of life }\end{array}$ \\
\hline $\begin{array}{l}\text { Fujiwara et al. [55] } \\
2011\end{array}$ & $\begin{array}{l}\text { nafamostat } \\
\text { mesylate }\end{array}$ & $\begin{array}{l}\text { human pancreatic } \\
\text { cancer cell lines } \\
\text { (AsPC-1, BxPC-3, } \\
\text { PANC-1) }\end{array}$ & $\begin{array}{l}\text { down-regulation of } \mathrm{IkB} \alpha, \mathrm{NF}-\kappa \mathrm{B} \\
\text { with reduction of ICAM-1, IL-8, } \\
\text { VEGF, MMP-9, uPA }\end{array}$ & $\begin{array}{l}\text { (1) increase of cell adhesion, } \\
\text { programmed cell death } \\
\text { (2) inhibition of angiogenesis, } \\
\text { invasion, metastasis in peritoneal } \\
\text { dissemination }\end{array}$ \\
\hline Gocho et al. [56] 2013 & $\begin{array}{l}\text { (1) nafamostat } \\
\text { mesylate } \\
\text { (2) nafamostat } \\
\text { mesylate } \\
\text { plus oxaliplatin }\end{array}$ & $\begin{array}{l}\text { human pancreatic } \\
\text { cancer cell line } \\
\text { (Panc-1) and } \\
\text { pancreatic cancer } \\
\text { mouse model }\end{array}$ & $\begin{array}{l}\text { down-regulation of NF- } \kappa \text { B with } \\
\text { reduction of ICAM-1, IL- } 8 \text {, } \\
\text { VEGF, MMP-9, uPA, c-IAP1, } \\
\text { c-IAP2 }\end{array}$ & $\begin{array}{l}\text { (1) increase of cell adhesion, } \\
\text { caspase-8-mediated apoptosis } \\
\text { (2) inhibition of PARP, } \\
\text { angiogenesis, invasion and } \\
\text { metastasis, } \\
\text { (3) synergistic cytotoxic effect }\end{array}$ \\
\hline
\end{tabular}

PAR-2, Protease-activated receptor-2; MAPK, mitogen-activated protein kinase; COX, cyclooxygenase; IL, Interleukin; GM-CSF, Granulocyte-macrophage colony stimulating factor; TAT, Tumor-associated trypsinogen; IkB, Inhibitor of NF- $\kappa \mathrm{B}$; NF- $\kappa \mathrm{B}$, Nuclear factor-kappaB; MMPs, metalloproteinases; uPA, urokinase-type plasminogen activator; ICAM-1, Intercellular Adhesion Molecule-1, VEGF, Vascular endothelial growth factor, IAP, Inhibitors of apoptosis.

a potential usefulness of $\mathrm{NM}$ in preoperative management of pancreatic cancer patients, because its use may reduce postoperative recurrences and improve survival by inhibition of metastasis induced by surgical resection [157]. Moreover, taking into account the improved outcomes and relatively low toxicity of preclinical and clinical studies of the combination therapy with traditional chemotherapeutic agents and NM, these combination chemotherapy regimens could represent a novel promising strategy for pancreatic cancer treatment.

The above studies are summarized in Table 2 .

3.3. Tranilast. Among pharmacological agents that affect several inflammatory and allergic pathways mediated by MCs tryptase, also tranilast (TN) has progressively attracted considerable attention because of its antitumor potential. Since 1982, this drug has been approved in Japan and Korea for the systemic and topical treatment of bronchial asthma, atopic dermatitis, and allergic conjunctivitis, with indications for keloids and hypertrophic scar added in 1993 [158]. Followup studies have revealed that clinical effectiveness of TN in such applications depends on inhibition of the release of biologically active mediators from MCs $[158,159]$. Moreover, tranilast was reported to inhibit the VEGF-induced angiogenesis both in vitro and in vivo, and most notably, these antiangiogenic activities have been shown to be concomitant with inhibitory effects on MCs degranulation [160].

TN was also reported to inhibit the release of TGFbeta, IL-1beta, prostaglandin (PG) $\mathrm{E}_{2}$, and IL-2 from human 
monocytes and macrophages [161, 162]. In the late 1980s, Isaji et al. [160] discovered the antiproliferative properties of TN. In particular, it was found that this agent inhibited fibroblast proliferation in vitro, resulting in suppression of proliferative inflammation in vivo. Subsequent studies confirmed the ability of TN in inhibiting tumor cell growth and proliferation in various models of cancer $[59,163,164]$. Overall, data from in vitro and in vivo models for proliferative disorders, clinical studies, and case reports have corroborated the antiproliferative and antitumor potential of TN [165], providing important insights into its mechanisms of action. Two studies, addressing antiproliferative activity of TN in several breast cancer cell lines, revealed that $\mathrm{TN}$ inhibits cell proliferation, by arresting cell cycle progression, and downregulates TGF- $\beta$ signaling pathway $[57,58]$. Moreover, Chakrabarti et al. [57] demonstrated that TN is able to inhibit MAPK signaling pathway.

$\mathrm{TN}$ was also reported to suppress the proliferation of cultured human leiomyoma cells by inhibiting cell cycle modulators, such as cyclin-dependent kinase 2 (CDK-2) [164].

As concerns pancreatic cancer, Hiroi et al. [59] reported that TN significantly inhibited proliferation of PGHAM-1, a hamster pancreatic cancer cell line. Moreover, TN was able to inhibit tumor angiogenesis in response to VEGF. Interestingly, in another study by Mitsuno et al. [60] TN was found to enhance chemotherapeutic effect of gemcitabine, as above reported for NM [53, 54]. However, unlike NMinduced effect, this chemosensitization was associated with the downregulation of ribonucleotide reductase M1 (RRM1) $[53,54]$.

Further experiments revealed that TN treatment inhibited prostate cancer cell proliferation in vitro by promoting apoptosis. In addition, it was reported the ability of TN to downregulate TGF-beta production from bone stromal cells and other different cell types, thereby suppressing TGF- $\beta$ stimulated osteoclast differentiation which underlies, in part, osteoblastic bone metastasis [61, 166]. Noguchi et al. [62] demonstrated that three weeks of TN treatment significantly reduced the tumor growth and metastasis, when administered daily by intraperitoneal injection ( $4 \mathrm{mg} / \mathrm{animal})$, in a mouse model of oral squamous cell carcinoma. TN has also been reported to exert antitumor effects in gastric cancer [63] and malignant glioma [64] through different mechanisms. Izumi et al. [61] have reported that the treatment with oral $\mathrm{TN}$ (300 mg/day) promoted a reduction of prostate-specific antigen (PSA) levels in 4 out of 16 patients with advanced castration-resistant prostate cancer (CRPC). Accordingly, in the subsequent follow-up pilot study, oral treatment with TN ( $300 \mathrm{mg} /$ day) for a median period of five months documented a continuous PSA inhibition in 3 out of 21 patients with advanced CRPC. Overall survival rates at 12 and 24 months were $74.5 \%$ and $61.5 \%$, respectively [167]. As a whole, these results suggest that TN could be used to improve the prognosis of patients with advanced CRPC. However, the two clinical investigations had some limitations: (1) open-label studies with one arm; (2) short follow-up period; (3) small sample size; (4) all patients were Japanese. Therefore, the reported findings need further confirmation. Finally, several case studies have reported that transdermal application of TN was able to relieve both itching and pain associated with hypertrophic, keloid scars [168].

Several important pathways have been recognized as potential targets of TN antitumor activity. In particular, the TN inhibitory effects on cell proliferation depend mainly on its ability to interfere with TGF- $\beta$ signaling and also reduce TGF- $\beta$ secretion $[57,61,63,64]$. Also, TN-mediated inhibition of cell proliferation has been markedly associated with blockade of cell cycle progression and consequent cell arrest in the $G_{0} / G_{1}$ transition $[58,59,164,169]$. Probably, TN can induce cell cycle arrest also through the inhibition of calcium influx, which is crucial for $G_{1} / S$ transition, as demonstrated by Nie et al. [65]. After TN treatment, the induction of apoptosis has been reported in several breast and prostate cancer cell lines $[61,66]$. In particular, Subramaniam et al. [58] showed that TN induced p53 upregulation, enhanced RAC-alpha serine/threonine-protein kinase (AKT1) phosphorylation, and reduced phosphorylation of extracellular regulated kinase 2 (ERK2). Another work by Subramaniam et al. [66] detected an increased level of a PARP-cleavage product in human cancer cell lines treated with TN.

$\mathrm{TN}$ also acts as a nontoxic agonist of the aryl hydrocarbon receptor $(\mathrm{ARH})[58,170]$, whose function is involved in anticancer effects $[67,68]$ : ARH presence in the cell is critical for TN-mediated cell cycle arrest. Interestingly, the AHR also antagonizes TGF- $\beta$ activity [171] and exerts ligand-dependent inhibitory effects on NF- $\kappa \mathrm{B}$ signaling [172]. These AHRmediated activities may contribute to the antiproliferative, antiangiogenic, and antimetastatic effects of TN.

The ability of TN to inhibit MAPK signaling pathway could also explain its antimetastatic potential, because this pathway is known to be implicated during the epithelial to mesenchymal transition (EMT), which is important for tumor cell invasion [57]. Moreover, the downregulation of certain MMPs, such as MMP-9, contributes to TN-mediated inhibition of tumor cell invasion during metastasis: such reduction of MMP-9 levels has been also linked to inhibition of TGF- $\beta$ signaling [58].

In addition to the above detailed potential targets, the antitumor action of TN relies on the blocking of the release of chemical mediators from MCs [57, 61, 64, 159], which is also the mechanism responsible for its antiallergic and anti-inflammatory efficacy [158]. In agreement with this correlation, Yamamoto et al. [158] have recently documented that TN downregulated neurofibroma cell (NF1 cells) proliferation through not only suppression of cell-growth promoting pathways but also the inhibition of biologically active mediators by MCs. Interestingly, this study supports the involvement of tryptase in the antitumor activities of TN. Indeed, following its addition to NF1 cells cocultured with MCs, this agent was reported to significantly inhibit NF1 cell proliferation and lower the levels of TGF$\beta$, SCF, and tryptase. These findings suggest that TN inhibits tumor proliferation also through the downregulation of MC tryptase, whose PAR-2-mediated proliferative and angiogenic effects have been previously described $[50,76]$. Furthermore, tryptase has been reported to activate $\mathrm{PI} 3 \mathrm{~K} / \mathrm{PKB}$ pathway via PAR-2 cleavage/activation and subsequently upregulate 
TABLE 3: All studies mentioned above that have considered tranilast.

\begin{tabular}{|c|c|c|c|c|}
\hline Author, reference, year & Drug/s & Tumor target & $\begin{array}{l}\text { Molecular mechanisms } \\
\text { of action }\end{array}$ & Results \\
\hline $\begin{array}{l}\text { Chakrabarti et al. [57] } \\
2009\end{array}$ & tranilast & $\begin{array}{l}\text { several mouse, rat and } \\
\text { human breast cancer cell } \\
\text { lines }\end{array}$ & $\begin{array}{l}\text { (1) down-regulation of } \\
\text { TGF- } \beta \text { pathway } \\
\text { (2) inhibition of MAPK } \\
\text { pathway }\end{array}$ & $\begin{array}{l}\text { inhibition of tumor cell } \\
\text { proliferation, angiogenesis, } \\
\text { apoptosis, migration }\end{array}$ \\
\hline $\begin{array}{l}\text { Subramaniam et al. [58] } \\
2010\end{array}$ & tranilast & $\begin{array}{l}\text { mouse breast cancer cell } \\
\text { line ( } 4 \mathrm{~T} 1)\end{array}$ & $\begin{array}{l}\text { (1) down-regulation of } \\
\text { TGF- } \beta \text { pathway } \\
\text { (2) induction cell arrest } \\
\text { in the } \mathrm{G}_{0} / \mathrm{G}_{1} \text { transition, } \\
\text { PARP cleavage, AKT1 } \\
\text { phosphorylation } \\
\text { (3) up-regulation of } \mathrm{p} 53 \\
\text { (4) reduction of ERK1/2 } \\
\text { phosphorylation }\end{array}$ & $\begin{array}{l}\text { inhibition of tumor cell } \\
\text { proliferation, angiogenesis, } \\
\text { apoptosis, migration }\end{array}$ \\
\hline Hiroi et al. [59] 2002 & tranilast & $\begin{array}{l}\text { hamster pancreatic cancer } \\
\text { cell line (PGHAM-1) }\end{array}$ & $\begin{array}{l}\text { (1) down-regulation of } \\
\text { TGF- } \beta \text { pathway with } \\
\text { reduction of MMP- } 9 \text { and } \\
\text { VEGF levels } \\
\text { (2) induction cell arrest } \\
\text { in the } G_{0} / G_{1} \text { transition }\end{array}$ & $\begin{array}{l}\text { inhibition of tumor cell } \\
\text { proliferation, angiogenesis }\end{array}$ \\
\hline Mitsuno et al. [60] 2010 & $\begin{array}{l}\text { (1) tranilast plus } \\
\text { gemcitabine } \\
\text { (2) gemcitabine }\end{array}$ & $\begin{array}{l}\text { human pancreatic cancer } \\
\text { cell line (KP4) }\end{array}$ & $\begin{array}{l}\text { decrease of RRM1 } \\
\text { expression }\end{array}$ & $\begin{array}{l}\text { (1) inhibition of tumor cell } \\
\text { proliferation, angiogenesis, } \\
\text { apoptosis } \\
\text { (2) synergistic cytotoxic } \\
\text { effect of combination } \\
\text { therapy }\end{array}$ \\
\hline Izumi et al. [61] 2009 & tranilast & $\begin{array}{l}\text { (1) prostate cancer cell lines } \\
\text { and bone-derived stromal } \\
\text { cells } \\
\text { (2) SCID mice } \\
\text { (3) advanced } \\
\text { hormone-refractory } \\
\text { prostaste cancer ( } 21 \text { pts) }\end{array}$ & $\begin{array}{l}\text { down-regulation of } \\
\text { TGF- } \beta 1 \text { pathway }\end{array}$ & $\begin{array}{l}\text { (1) induction of apoptosis } \\
\text { (2) reduction of invasion } \\
\text { and bone metastasis, PSA } \\
\text { levels, improve prognosis }\end{array}$ \\
\hline Noguchi et al. [62] 2003 & tranilast & $\begin{array}{l}\text { mouse model of oral } \\
\text { squamous cell carcinoma }\end{array}$ & not analyzed & $\begin{array}{l}\text { decrease of tumor growth, } \\
\text { angiogenesis, cervical } \\
\text { lymph node metastases }\end{array}$ \\
\hline Yashiro et al. [63] 2003 & tranilast & $\begin{array}{l}\text { human gastric carcinoma } \\
\text { cell line (OCUM-2D) and } \\
\text { gastric fibroblast cell line } \\
\text { (NF-10) }\end{array}$ & $\begin{array}{l}\text { down-regulation of } \\
\text { TGF- } \beta \text { pathway }\end{array}$ & $\begin{array}{l}\text { decrease of tumor growth, } \\
\text { angiogenesis, invasion }\end{array}$ \\
\hline Platten et al. [64] 2001 & tranilast & $\begin{array}{l}\text { human malignant glioma } \\
\text { cell line }\end{array}$ & $\begin{array}{l}\text { down-regulation of } \\
\text { TGF- } \beta 1-2 \text { pathway }\end{array}$ & $\begin{array}{l}\text { decrease of tumor growth, } \\
\text { angiogenesis, migration, } \\
\text { invasion }\end{array}$ \\
\hline Nie et al. [65] 1997 & tranilast & $\begin{array}{l}\text { breast cancer cell lines } \\
(\mathrm{MCF}-7)\end{array}$ & $\begin{array}{l}\text { induction cell arrest in } \\
\text { the } G_{0} / G_{1} \text { transition }\end{array}$ & decrease of tumor growth \\
\hline $\begin{array}{l}\text { Subramaniam et al. [66] } \\
2011\end{array}$ & tranilast & $\begin{array}{l}\text { human breast cancer cell } \\
\text { lines (triple } \\
\text { positive-BT-474, triple } \\
\text { negative-MDA-MB-231) }\end{array}$ & $\begin{array}{l}\text { (1) up-regulation of p53 } \\
\text { (2) induction cell arrest } \\
\text { in the } G_{0} / G_{1} \text { transition, } \\
\text { AKT1 and ERK2 } \\
\text { phosphorylation, } \\
\text { PARP-cleavage product }\end{array}$ & $\begin{array}{l}\text { induction of apoptosis, } \\
\text { tumor growth, migration }\end{array}$ \\
\hline Zhang et al. [67] 2009 & tranilast & $\begin{array}{l}\text { several ER negative human } \\
\text { breast cancer cell lines }\end{array}$ & $\begin{array}{l}\text { agonizing ARH with } \\
\text { down-regulation of } \\
\text { TGF- } \beta \text { and NF- } \kappa \text { B } \\
\text { pathways }\end{array}$ & $\begin{array}{l}\text { (1) induction of apoptosis } \\
\text { (2) inhibition of } \\
\text { angiogenesis, cell growth, } \\
\text { invasion and metastasis }\end{array}$ \\
\hline Hall et al. [68] 2010 & tranilast & $\begin{array}{l}\text { several human breast } \\
\text { cancer cell lines }\end{array}$ & $\begin{array}{l}\text { agonizing ARH with } \\
\text { down-regulation of } \\
\text { TGF- } \beta \text { and NF- } \kappa \text { B } \\
\text { pathways }\end{array}$ & $\begin{array}{l}\text { (1) induction of apoptosis } \\
\text { (2) inhibition of } \\
\text { angiogenesis, cell growth, } \\
\text { invasion and metastasis }\end{array}$ \\
\hline
\end{tabular}


TABLe 3: Continued.

\begin{tabular}{lllll}
\hline Author, reference, year & Drug/s & Tumor target & $\begin{array}{l}\text { Molecular mechanisms } \\
\text { of action }\end{array}$ & Results \\
\hline Isaji et al. [69] 1997 & tranilast & $\begin{array}{l}\text { human pancreatic cancer } \\
\text { cell lines }\end{array}$ & $\begin{array}{l}\text { decrease of VEGF and } \\
\text { MMPs levels }\end{array}$ & $\begin{array}{l}\text { inhibition of angiogenesis, } \\
\text { cell growth, migration }\end{array}$ \\
\hline
\end{tabular}

TGF- $\beta 1$, Tumor growth factor-betal, MMPs, metalloproteinases; MAPK, mitogen-activated protein kinase uPA, PARP, poly ADP-ribose polymerase; urokinase-type plasminogen activator; AKT1, RAC-alpha serine/threonine-protein kinase; ERK, Extracellular regulated kinase 2; VEGF, Vascular endothelial growth factor; RRM1, Ribonucleotide reductase M1.

NF- $\kappa$ B expression [154], promoting tumor cell survival and chemoresistance $[56,155,156]$. Thus, the inhibition of tryptase release may represent a further molecular mechanism involved in the induction of apoptosis and cell cycle arrest upon TN treatment. Because tryptase-mediated PAR2 activation triggers the MAPK signaling pathway, which is involved in the EMT process [57], tryptase inhibition by $\mathrm{TN}$ may also mediate its anti-invasion and antimetastatic properties.

The inhibitory effect on tryptase release could contribute to the ability of TN treatment to target TGF-beta-regulated signaling cascade and reduce TGF- $\beta$ production. As above described, indeed, in the tumor microenvironment, tryptase may upregulate uPA levels, $[25,26,75]$ thereby activating latent TGF- $\beta$ which, in turn, upregulates the production of uPA, MMP-2, and VEGF. This vicious cycle has been implicated in angiogenesis, tumor cell invasion, and metastasis [94]. By the way, tryptase can also participate to the neovascular growth by activating latent MMPs, which, in turn, promote tumor invasiveness and release of angiogenic factors (VEGF or FGF-2) from their matrix-bound state [25, $26,75]$. Therefore, also taking into account the previously reported study by Isaji et al. [69], the downregulation of tryptase release may probably contribute to the TN-induced inhibition of tumor angiogenesis in response to VEGF, as observed in experimental pancreatic cancer [59].

In the light of the exposed considerations, we suggest that the inhibition of tryptase functions may underlie the anti-invasion, antimetastatic, and antiangiogenic effects of TN treatment. As concerns safety, TN shows relatively low toxicity in $[61,69,173]$, making it a promising candidate for further clinical investigations. Based on the encouraging in vitro and in vivo research data, TN seems to be a safe and effective agent for the treatment of several proliferative and angiogenic diseases.

The above studies are summarized in Table 3.

\section{Concluding Remarks}

Several literature data support a potential implication of MCs tryptase in three pivotal processes involved in cancer development and metastasization: cell growth, tumor-induced angiogenesis, and invasion [174, 175]. Therefore, this serine protease may be considered a novel promising target for the adjuvant treatment of tumors through the selective inhibition of angiogenesis, proliferation, and tissue remodelling. In agreement with these considerations, compounds targeting tryptase functions, although designed as antiallergic drugs, could exert a useful antitumor activity as well. In this regard, it is of interest to underline that many new anticancer drugs used in clinical field, such as sorafenib [18], sunitinib [176], pazopanib [177] axitinib [178], and masitinib [179] are all targeted against c-KitR, whose activation leads to the release of tryptase by MCs [24].

In particular, we herein discuss the antitumor and antiangiogenic potential of three agents which are able to inhibit the functions of MCs tryptase: gabexate mesylate, nafamostat mesylate, and tranilast. Although no definitive experimental data are available to confirm the role that tryptase released from mast cells stimulate tumor angiogenesis, the above hypothesis is supported by a pilot study in the in vivo chorioallantoic membrane assay [16]. In this study an angiogenic activity of human recombinant tryptase comparable to the angiogenic activity induced by the VEGF has been demonstrated. Data from this study suggest that the inhibition of tryptase is intriguing hypothesis worthy to further investigation.

The new antiangiogenic approach here reviewed should be substantially strengthened by future awaited clinical studies having the aim to evaluate the truly efficacy of the tryptase inhibitors as a novel tumor antiangiogenic therapy.

\section{Disclosure}

All authors have no financial or personal relationships with other people or organizations that could inappropriately influence their work.

\section{Conflict of Interests}

The authors declare that there is no conflict of interests regarding the publication of this paper.

\section{References}

[1] J. Folkman and Y. Shing, "Angiogenesis," Journal of Biological Chemistry, vol. 267, no. 16, pp. 10931-10934, 1992.

[2] G. Breier, "Angiogenesis in embryonic development-a review," Placenta, vol. 21, supplement A, pp. S11-S15, 2000.

[3] M. L. Iruela-Arispe and H. F. Dvorak, "Angiogenesis: a dynamic balance of stimulators and inhibitors," Thrombosis and Haemostasis, vol. 78, no. 1, pp. 672-677, 1997.

[4] T. O. Daniel and D. Abrahamson, "Endothelial signal integration in vascular assembly," Annual Review of Physiology, vol. 62, pp. 649-671, 2000.

[5] T. V. Petrova, T. Makinen, and K. Alitalo, "Signaling via vascular endothelial growth factor receptors," Experimental Cell Research, vol. 253, no. 1, pp. 117-130, 1999. 
[6] M. A. Nugent and R. V. Iozzo, "Fibroblast growth factor-2," The International Journal of Biochemistry and Cell Biology, vol. 32, no. 2, pp. 115-120, 2000.

[7] C. D. Gadaleta and G. Ranieri, "Trans-arterial chemoembolization as a therapy for liver tumours: new clinical developments and suggestions for combination with angiogenesis inhibitors," Critical Reviews in Oncology/Hematology, vol. 80, no. 1, pp. 4053, 2011

[8] G. Ranieri, M. Ammendola, R. Patruno et al., "Tryptasepositive mast cells correlate with angiogenesis in early breast cancer patients," International Journal of Oncology, vol. 35, no. 1, pp. 115-120, 2009.

[9] D. D. Roberts, "Regulation of tumor growth and metastasis by thrombospondin-1," FASEB Journal, vol. 10, no. 10, pp. 1183-1191, 1996.

[10] M. S. O’Reilly, L. Holmgren, Y. Shing et al., "Angiostatin: a novel angiogenesis inhibitor that mediates the suppression of metastases by a Lewis lung carcinoma," Cell, vol. 79, no. 2, pp. 315-328, 1994.

[11] M. S. O’Reilly, T. Boehm, Y. Shing et al., "Endostatin: an endogenous inhibitor of angiogenesis and tumor growth," Cell, vol. 88 , no. 2, pp. 277-285, 1997.

[12] G. Ranieri, M. Pantaleo, M. Piccinno et al., "Tyrosine kinase inhibitors (TKIs) in human and pet tumours with special reference to breast cancer: a comparative review," Critical Reviews in Oncology/Hematology, vol. 88, no. 2, pp. 293-308, 2013.

[13] G. Ranieri, C. D. Gadaleta, R. Patruno et al., "A model of study for human cancer: spontaneous occurring tumors in dogs: biological features and translation for new anticancer therapies," Critical Reviews in Oncology/Hematology, vol. 88, no. 1, pp. 187197, 2013.

[14] J. P. Kankkunen, I. T. Harvima, and A. Naukkarinen, "Quantitative analysis of tryptase and chymase containing mast cells in benign and malignant breast lesions," International Journal of Cancer, vol. 72, no. 3, pp. 385-338, 1997.

[15] L. Soucek, E. R. Lawlor, D. Soto, K. Shchors, L. B. Swigart, and G. I. Evan, "Mast cells are required for angiogenesis and macroscopic expansion of Myc-induced pancreatic islet tumors," Nature Medicine, vol. 13, no. 10, pp. 1211-1218, 2007.

[16] D. Ribatti, G. Ranieri, B. Nico, V. Benagiano, and E. Crivellato, "Tryptase and chymase are angiogenic in vivo in the chorioallantoic membrane assay," International Journal of Developmental Biology, vol. 55, no. 1, pp. 99-102, 2011.

[17] A. Mangia, A. Malfettone, R. Rossi et al., "Tissue remodelling in breast cancer: human mast cell tryptase as an initiator of myofibroblast differentiation," Histopathology, vol. 58, no. 7, pp. 1096-1106, 2011.

[18] G. Ranieri, G. Gadaleta-Caldarola, V. Goffredo et al., "Sorafenib (BAY 43-9006) in hepatocellular carcinoma patients: from discovery to clinical development," Current Medicinal Chemistry, vol. 19, no. 7, pp. 938-944, 2012.

[19] G. Ranieri, L. Passantino, R. Patruno et al., "The dog mast cell tumour as a model to study the relationship between angiogenesis, mast cell density and tumour malignancy," Oncology Reports, vol. 10, no. 5, pp. 1189-1193, 2003.

[20] G. Ranieri, A. Labriola, G. Achille et al., "Microvessel density, mast cell density and thymidine phosphorylase expression in oral squamous carcinoma," International Journal of Oncology, vol. 21, no. 6, pp. 1317-1323, 2002.

[21] M. Gulubova and T. Vlaykova, "Prognostic significance of mast cell number and microvascular density for the survival of patients with primary colorectal cancer," Journal of Gastroenterology and Hepatology, vol. 24, no. 7, pp. 1265-1275, 2009.

[22] H. Yano, M. Kinuta, H. Tateishi et al., "Mast cell infiltration around gastric cancer cells correlates with tumour angiogenesis and metastasis," Gastric Cancer, vol. 2, no. 1, pp. 26-32, 1999.

[23] M. Ammendola, R. Sacco, G. Donato et al., "Mast cell positivity to tryptase correlates with metastatic lymph nodes in gastrointestinal cancer patients treated surgically," Oncology, vol. 85, no. 2, pp. 111-116, 2013.

[24] T. C. Moon, E. Lee, S.-H. Baek et al., "Degranulation and cytokine expression in human cord blood-derived mast cells cultured in serum-free medium with recombinant human stem cell factor," Molecules and Cells, vol. 16, no. 2, pp. 154-160, 2003.

[25] W. R. Sperr, K. Czerwenka, G. Mundigler et al., "Specific activation of human mast cells by the ligand for c-Kit: comparison between lung, uterus and heart mast cells," International Archives of Allergy and Immunology, vol. 102, no. 2, pp. 170-175, 1993.

[26] A. Iemura, M. Tsai, A. Ando, B. K. Wershil, and S. J. Galli, "The c-kit ligand, stem cell factor, promotes mast cell survival by suppressing apoptosis," The American Journal of Pathology, vol. 144, no. 2, pp. 321-328, 1994.

[27] M. F. Gurish and K. F. Austen, "The diverse roles of mast cells," The Journal of Experimental Medicine, vol. 194, no. 1, pp. 1-5, 2001.

[28] Y. B. Shaik-Dasthagirisaheb, G. Varvara, G. Murmura et al., "Vascular endothelial growth factor (VEGF), mast cells and inflammation," International Journal of Immunopathology and Pharmacology, vol. 26, no. 2, pp. 327-335, 2013.

[29] I. Puxeddu, D. Ribatti, E. Crivellato, and F. Levi-Schaffer, "Mast cells and eosinophils: a novel link between inflammation and angiogenesis in allergic diseases," Journal of Allergy and Clinical Immunology, vol. 116, no. 3, pp. 531-536, 2005.

[30] J. S. Marshall, "Mast-cell responses to pathogens," Nature Reviews Immunology, vol. 4, no. 10, pp. 787-799, 2004.

[31] E. Crivellato and D. Ribatti, “The mast cell: an evolutionary perspective," Biological Reviews of the Cambridge Philosophical Society, vol. 85, no. 2, pp. 347-360, 2010.

[32] D. Ribatti, E. Crivellato, L. Candussio et al., "Mast cells and their secretory granules are angiogenic in the chick embryo chorioallantoic membrane," Clinical and Experimental Allergy, vol. 31, no. 4, pp. 602-608, 2001.

[33] S. J. Galli, J. Kalesnikoff, M. A. Grimbaldeston, A. M. Piliponsky, C. M. M. Williams, and M. Tsai, "Mast cells as "tunable" effector and immunoregulatory cells: recent advances," Annual Review of Immunology, vol. 23, pp. 749-786, 2005.

[34] M. A. Beaven, "Our perception of the mast cell from Paul Ehrlich to now," European Journal of Immunology, vol. 39, no. 1, pp. 11-25, 2009.

[35] K. Oda and H. Kitano, "A comprehensive map of the toll-like receptor signaling network," Molecular Systems Biology, vol. 2, Article ID 2006.0015, 2006.

[36] L. M. Coussens, W. W. Raymond, G. Bergers et al., "Inflammatory mast cells up-regulate angiogenesis during squamous epithelial carcinogenesis," Genes and Development, vol. 13, no. 11, pp. 1382-1397, 1999.

[37] T. Nakayama, L. Yao, and G. Tosato, "Mast cell-derived angiopoietin-1 plays a critical role in the growth of plasma cell tumors," The Journal of Clinical Investigation, vol. 114, no. 9, pp. 1317-1325, 2004. 
[38] T. C. Theoharides and P. Conti, "Mast cells: the JEKYLL and HYDE of tumor growth," Trends in Immunology, vol. 25, no. 5, pp. 235-241, 2004.

[39] D. Ribatti and E. Crivellato, "Mast cells, angiogenesis and cancer," Advances in Experimental Medicine and Biology, vol. 716, pp. 270-288, 2011.

[40] D. Ribatti, D. Guidolin, A. Marzullo et al., "Mast cells and angiogenesis in gastric carcinoma," International Journal of Experimental Pathology, vol. 91, no. 4, pp. 350-356, 2010.

[41] D. Ribatti, N. Finato, E. Crivellato et al., "Neovascularization and mast cells with tryptase activity increase simultaneously with pathologic progression in human endometrial cancer," The American Journal of Obstetrics and Gynecology, vol. 193, no. 6, pp. 1961-1965, 2005.

[42] S. J. Galli and M. Tsai, "Mast cells: versatile regulators of inflammation, tissue remodeling, host defense and homeostasis," Journal of Dermatological Science, vol. 49, no. 1, pp. 7-19, 2008.

[43] A. M. Gilfillan and C. Tkaczyk, "Integrated signalling pathways for mast-cell activation," Nature Reviews Immunology, vol. 6, no. 3, pp. 218-230, 2006.

[44] S. C. Bischoff, "Physiological and pathophysiological functions of intestinal mast cells," Seminars in Immunopathology, vol. 31, no. 2, pp. 185-205, 2009.

[45] T. C. Theoharides, D. Kempuraj, M. Tagen, P. Conti, and D. Kalogeromitros, "Differential release of mast cell mediators and the pathogenesis of inflammation," Immunological Reviews, vol. 217, no. 1, pp. 65-78, 2007.

[46] W.-H. Yoon, Y.-J. Jung, T.-D. Kim et al., "Gabexate mesilate inhibits colon cancer growth, invasion, and metastasis by reducing matrix metalloproteinases and angiogenesis," Clinical Cancer Research, vol. 10, no. 13, pp. 4517-4526, 2004.

[47] G. Brandi, S. Tavolari, F. de Rosa et al., "Antitumoral efficacy of the protease inhibitor gabexate mesilate in colon cancer cells harbouring KRAS, BRAF and PIK3CA mutations," PLOS ONE, vol. 7, no. 7, Article ID e41347, 2012.

[48] Y. Uchima, T. Sawada, T. Nishihara et al., "Identification of a trypsinogen activity stimulating factor produced by pancreatic cancer cells: its role in tumor invasion and metastasis," International Journal of Molecular Medicine, vol. 12, no. 6, pp. 871-878, 2003.

[49] A. Jikuhara, M. Yoshii, H. Iwagaki, S. Mori, M. Nishibori, and N. Tanaka, "MAP kinase-mediated proliferation of DLD1 carcinoma by the stimulation of protease-activated receptor 2," Life Sciences, vol. 73, no. 22, pp. 2817-2829, 2003.

[50] M. Yoshii, A. Jikuhara, S. Mori et al., "Mast cell tryptase stimulates DLD-1 carcinoma through prostaglandin-and MAP kinase-dependent manners," Journal of Pharmacological Sciences, vol. 98, no. 4, pp. 450-458, 2005.

[51] H. Tajima, T. Ohta, A. Elnemr et al., "Enhanced invasiveness of pancreatic adenocarcinoma cells stably transfected with cationic trypsinogen cDNA," International Journal of Cancer, vol. 94, no. 5, pp. 699-704, 2001.

[52] T. Ohta, K. Shimizu, S. Yi et al., "Protease-activated receptor-2 expression and the role of trypsin in cell proliferation in human pancreatic cancers," International Journal of Oncology, vol. 23, no. 1, pp. 61-66, 2003.

[53] T. Uwagawa, P. J. Chiao, T. Gocho, S. Hirohara, T. Misawa, and K. Yanaga, "Combination chemotherapy of nafamostat mesilate with gemcitabine for pancreatic cancer targeting NF$\kappa \mathrm{B}$ activation," Anticancer Research, vol. 29, no. 8, pp. 3173-3178, 2009.
[54] T. Uwagawa, T. Misawa, T. Sakamoto et al., "A phase I study of full-dose gemcitabine and regional arterial infusion of nafamostat mesilate for advanced pancreatic cancer," Annals of Oncology, vol. 20, no. 2, pp. 239-243, 2009.

[55] Y. Fujiwara, K. Furukawa, K. Haruki et al., "Nafamostat mesilate can prevent adhesion, invasion and peritoneal dissemination of pancreatic cancer thorough nuclear factor kappa-B inhibition," Journal of Hepato-Biliary-Pancreatic Sciences, vol. 18, no. 5, pp. 731-739, 2011.

[56] T. Gocho, T. Uwagawa, K. Furukawa et al., "Combination chemotherapy of serine protease inhibitor nafamostat mesilate with oxaliplatin targeting NF- $\kappa \mathrm{B}$ activation for pancreatic cancer," Cancer Letters, vol. 333, no. 1, pp. 89-95, 2013.

[57] R. Chakrabarti, V. Subramaniam, S. Abdalla, S. Jothy, and G. J. Prud'homme, "Tranilast inhibits the growth and metastasis of mammary carcinoma," Anti-Cancer Drugs, vol. 20, no. 5, pp. 334-345, 2009.

[58] V. Subramaniam, R. Chakrabarti, G. J. Prud'Homme, and S. Jothy, "Tranilast inhibits cell proliferation and migration and promotes apoptosis in murine breast cancer," Anti-Cancer Drugs, vol. 21, no. 4, pp. 351-361, 2010.

[59] M. Hiroi, M. Onda, E. Uchida, and T. Aimoto, "Anti-tumor effect of $\mathrm{N}$-[3,4-dimethoxycinnamoyl]-anthranilic acid (tranilast) on experimental pancreatic cancer," Journal of Nippon Medical School, vol. 69, no. 3, pp. 224-234, 2002.

[60] M. Mitsuno, Y. Kitajima, K. Ohtaka et al., "Tranilast strongly sensitizes pancreatic cancer cells to gemcitabine via decreasing protein expression of ribonucleotide reductase 1," International Journal of Oncology, vol. 21, no. 4, pp. 351-361, 2010.

[61] K. Izumi, A. Mizokami, Q. L. You et al., "Tranilast inhibits hormone refractory prostate cancer cell proliferation and suppresses transforming growth factor $\beta 1$-associated osteoblastic changes," Prostate, vol. 69, no. 11, pp. 1222-1234, 2009.

[62] N. Noguchi, S. Kawashiri, A. Tanaka, K. Kato, and H. Nakaya, "Effects of fibroblast growth inhibitor on proliferation and metastasis of oral squamous cell carcinoma," Oral Oncology, vol. 39, no. 3, pp. 240-247, 2003.

[63] M. Yashiro, K. Murahashi, T. Matsuoka et al., “Tranilast (N3,4 -dimethoxycinamoyl anthranilic acid): a novel inhibitor of invasion-stimulating interaction between gastric cancer cells and orthotopic fibroblasts," Anticancer Research, vol. 23, no. 5A, pp. 3899-3904, 2003.

[64] M. Platten, C. Wild-Bode, W. Wick, J. Leitlein, J. Dichgans, and M. Weller, "N-[3,4-dimethoxycinnamoyl]-anthranilic acid (tranilast) inhibits transforming growth factor- $\beta$ release and reduces migration and invasiveness of human malignant glioma cells," International Journal of Cancer, vol. 93, no. 1, pp. 53-61, 2001.

[65] L. Nie, Y. Oishi, I. Doi, H. Shibata, and I. Kojima, "Inhibition of proliferation of MCF-7 breast cancer cells by a blocker of $\mathrm{Ca}^{2+}$ permeable channel," Cell Calcium, vol. 22, no. 2, pp. 75-82, 1997.

[66] V. Subramaniam, O. Ace, G. J. Prud'homme, and S. Jothy, "Tranilast treatment decreases cell growth, migration and inhibits colony formation of human breast cancer cells," Experimental and Molecular Pathology, vol. 90, no. 1, pp. 116-122, 2011.

[67] S. Zhang, P. Lei, X. Liu et al., “The aryl hydrocarbon receptor as a target for estrogen receptor-negative breast cancer chemotherapy," Endocrine-Related Cancer, vol. 16, no. 3, pp. 835-844, 2009.

[68] J. M. Hall, M. A. Barhoover, D. Kazmin, D. P. McDonnell, W. F. Greenlee, and R. S. Thomas, "Activation of the arylhydrocarbon receptor inhibits invasive and metastatic features 
of human breast cancer cells and promotes breast cancer cell differentiation," Molecular Endocrinology, vol. 24, no. 2, pp. 359$369,2010$.

[69] M. Isaji, H. Miyata, Y. Ajisawa, Y. Takehana, and N. Yoshimura, "Tranilast inhibits the proliferation, chemotaxis and tube formation of human microvascular endothelial cells in vitro and angiogenesis in vivo," British Journal of Pharmacology, vol. 122, no. 6, pp. 1061-1066, 1997.

[70] S. Ch'ng, R. A. Wallis, L. Yuan, P. F. Davis, and S. T. Tan, "Mast cells and cutaneous malignancies," Modern Pathology, vol. 19, no. 1, pp. 149-159, 2006.

[71] R.-M. Amini, K. Aaltonen, H. Nevanlinna et al., "Mast cells and eosinophils in invasive breast carcinoma," BMC Cancer, vol. 7, article 165, 2007.

[72] S. Maltby, K. Khazaie, and K. M. McNagny, "Mast cells in tumor growth: angiogenesis, tissue remodelling and immunemodulation," Biochimica et Biophysica Acta-Reviews on Cancer, vol. 1796, no. 1, pp. 19-26, 2009.

[73] K. Norrby, "Mast cells and angiogenesis," APMIS, vol. 110, no. 5, pp. 355-371, 2002.

[74] D. D. Metcalfe, D. Baram, and Y. A. Mekori, "Mast cells," Physiological Reviews, vol. 77, no. 4, pp. 1033-1079, 1997.

[75] R. J. Blair, H. Meng, M. J. Marchese et al., "Human mast cells stimulate vascular tube formation. Tryptase is a novel, potent angiogenic factor," The Journal of Clinical Investigation, vol. 99, no. 11, pp. 2691-2700, 1997.

[76] A. F. Milia, M. B. Salis, T. Stacca et al., "Protease-activated receptor-2 stimulates angiogenesis and accelerates hemodynamic recovery in a mouse model of hindlimb ischemia," Circulation Research, vol. 91, no. 4, pp. 346-352, 2002.

[77] Y. Liu and B. M. Mueller, "Protease-activated receptor-2 regulates vascular endothelial growth factor expression in MDAMB-231 cells via MAPK pathways," Biochemical and Biophysical Research Communications, vol. 344, no. 4, pp. 1263-1270, 2006.

[78] W. Zhang, G. Stoica, S. I. Tasca, K. A. Kelly, and C. J. Meininger, "Modulation of tumor angiogenesis by stem cell factor," Cancer Research, vol. 60, no. 23, pp. 6757-6762, 2000.

[79] B. Huang, Z. Lei, G.-M. Zhang et al., "SCF-mediated mast cell infiltration and activation exacerbate the inflammation and immunosuppression in tumor microenvironment," Blood, vol. 112, no. 4, pp. 1269-1279, 2008.

[80] D. Ribatti, A. Vacca, R. Ria et al., "Neovascularisation, expression of fibroblast growth factor-2, and mast cells with tryptase activity increase simultaneously with pathological progression in human malignant melanoma," European Journal of Cancer, vol. 39, no. 5, pp. 666-674, 2003.

[81] D. Ribatti, M. G. Ennas, A. Vacca et al., "Tumor vascularity and tryptase-positive mast cells correlate with a poor prognosis in melanoma," European Journal of Clinical Investigation, vol. 33, no. 5, pp. 420-425, 2003.

[82] D. Ribatti, N. Finato, E. Crivellato et al., "Angiogenesis and mast cells in human breast cancer sentinel lymph nodes with and without micrometastases," Histopathology, vol. 51, no. 6, pp. 837-842, 2007.

[83] D. Ribatti, A. S. Belloni, B. Nico et al., "Tryptase- and leptinpositive mast cells correlate with vascular density in uterine leiomyomas," The American Journal of Obstetrics and Gynecology, vol. 196, no. 5, pp. 470.el-470.e7, 2007.

[84] S. Yodavudh, S. Tangjitgamol, and S. Puangsa-art, "Prognostic significance of microvessel density and mast cell density for the survival of Thai patients with primary colorectal cancer,"
Journal of the Medical Association of Thailand, vol. 91, no. 5, pp. 723-732, 2008.

[85] D. Ribatti, S. Molica, A. Vacca et al., "Tryptase-positive mast cells correlate positively with bone marrow angiogenesis in Bcell chronic lymphocytic leukemia," Leukemia, vol. 17, no. 7, pp. 1428-1430, 2003.

[86] D. Ribatti, A. Vacca, B. Nico et al., "Bone marrow angiogenesis and mast cell density increase simultaneously with progression of human multiple myeloma," British Journal of Cancer, vol. 79, no. 3-4, pp. 451-455, 1999.

[87] D. Ribatti, G. Polimeno, A. Vacca et al., "Correlation of bone marrow angiogenesis and mast cells with tryptase activity in myelodysplastic syndromes," Leukemia, vol. 16, no. 9, pp. 1680$1684,2002$.

[88] H. J. Nielsen, U. Hansen, I. J. Christensen, C. M. Reimert, N. Brünner, and F. Moesgaard, "Independent prognostic value of eosinophil and mast cell infiltration in colorectal cancer tissue," The Journal of Pathology, vol. 189, no. 4, pp. 487-495, 1999.

[89] S. Aaltomaa, P. Lipponen, S. Papinaho, and V.-M. Kosma, "Mast cells in breast cancer," Anticancer Research, vol. 13, no. 3, pp. 785-788, 1993.

[90] S. Dabiri, D. Huntsman, N. Makretsov et al., "The presence of stromal mast cells identifies a subset of invasive breast cancers with a favorable prognosis," Modern Pathology, vol. 17, no. 6, pp. 690-695, 2004.

[91] T. J. Welsh, R. H. Green, D. Richardson, D. A. Waller, K. J. O'Byrne, and P. Bradding, "Macrophage and mast-cell invasion of tumor cell islets confers a marked survival advantage in nonsmall-cell lung cancer," Journal of Clinical Oncology, vol. 23, no. 35, pp. 8959-8967, 2005.

[92] F. Erba, L. Fiorucci, S. Pascarella, E. Menegatti, P. Ascenzi, and F. Ascoli, "Selective inhibition of human mast cell tryptase by gabexate mesylate, an antiproteinase drug," Biochemical Pharmacology, vol. 61, no. 3, pp. 271-276, 2001.

[93] S. Mori, Y. Itoh, R. Shinohata, T. Sendo, R. Oishi, and M. Nishibiro, "Nafamostat mesilate is an extremely potent inhibitor of human tryptase," Journal of Pharmacological Sciences, vol. 92, no. 4, pp. 420-423, 2003.

[94] Y. Uchima, T. Sawada, and K. Hirakawa, "Action of antiproteases on pancreatic cancer cells," Journal of the Pancreas, vol. 8, supplement 4, pp. 479-487, 2007.

[95] J. J. Martindale, The Extra Pharmacopeia, The Royal Pharmaceutical Society, London, UK, 31st edition, 1996.

[96] E. Menegatti, M. Bolognesi, S. Scalia, F. Bortolotti, M. Guarneri, and P. Ascenzi, "Gabexate mesylate inhibition of serine proteases: thermodynamic and computer-graphics analysis," Journal of Pharmaceutical Sciences, vol. 75, no. 12, pp. 1171-1174, 1986.

[97] R. Cortes, P. Ascenzi, M. Colasanti et al., "Cross-enzyme inhibition by gabexate mesylate: formulation and reactivity study," Journal of Pharmaceutical Sciences, vol. 87, no. 11, pp. 1335-1340, 1998.

[98] A.-P. Sappino, N. Busso, D. Belin, and J.-D. Vassalli, "Increase of urokinase-type plasminogen activator gene expression in human lung and breast carcinomas," Cancer Research, vol. 47, no. 15, pp. 4043-4046, 1987.

[99] M. Gottesman, "The role of proteases in cancer," Seminars in Cancer Biology, vol. 1, pp. 97-160, 1990.

[100] L. A. Liotta and W. G. Stetler-Stevenson, "Tumor invasion and metastasis: an imbalance of positive and negative regulation," Cancer Research, vol. 51, supplement 18, pp. 5045-5059, 1991. 
[101] R. Dahiya, W.-H. Yoon, R. Boyle, T. Schoenberg, T.-S. B. Yen, and P. Narayan, "Biochemical,cytogenetic, and morphological characteristics of human primary and metastatic prostate cancer cell lines," Biochemistry International, vol. 27, no. 4, pp. 567$577,1992$.

[102] W. G. Stetler-Stevenson, "Progelatinase A activation during tumor cell invasion," Invasion and Metastasis, vol. 95, no. 14, pp. 259-268, 1994.

[103] M. S. Pepper, "Role of the matrix metalloproteinase and plasminogen activator-plasmin systems in angiogenesis," Arteriosclerosis, Thrombosis, and Vascular Biology, vol. 21, no. 7, pp. 1104-1117, 2001.

[104] K. Naito, N. Kanbayashi, S. Nakajima et al., "Inhibition of growth of human tumor cells in nude mice by a metalloproteinase inhibitor," International Journal of Cancer, vol. 58, no. 5, pp. 730-735, 1994.

[105] S. A. Watson, T. M. Morris, G. Robinson, M. J. Crimmin, P. D. Brown, and J. D. Hardcastle, "Inhibition of organ invasion by the matrix metalloproteinase inhibitor batimastat (BB-94) in two human colon carcinoma metastasis models," Cancer Research, vol. 55, no. 16, pp. 3629-3633, 1995.

[106] R. Reich, E. W. Thompson, Y. Iwamoto et al., "Effects of inhibitors of plasminogen activator, serine proteinases, and collagenase IV on the invasion of basement membranes by metastatic cells," Cancer Research, vol. 48, no. 12, pp. 3307-3312, 1988.

[107] R. Benelli, R. Adatia, B. Ensoli, W. G. Stetler-Stevenson, L. Santi, and A. Albini, "Inhibition of AIDS-Kaposi's sarcoma cell induced endothelial cell invasion by TIMP-2 and a synthetic peptide from the metalloproteinase propeptide: Implications for an anti-angiogenic therapy," Oncology Research, vol. 6, no. 6, pp. 251-257, 1994.

[108] B. Anand-Apte, M. S. Pepper, E. Voest et al., "Inhibition of angiogenesis by tissue inhibitor of metalloproteinase-3," Investigative Ophthalmology and Visual Science, vol. 38, no. 5, pp. 817-823, 1997.

[109] N. Hiraoka, E. Allen, I. J. Apel, M. R. Gyetko, and S. J. Weiss, "Matrix metalloproteinases regulate neovascularization by acting as pericellular fibrinolysins," Cell, vol. 95, no. 3, pp. 365-377, 1998.

[110] M. Nguyen, J. Arkell, and C. J. Jackson, "Thrombin rapidly and efficiently activates gelatinase $\mathrm{A}$ in human microvascular endothelial cells via a mechanism independent of active MT1 matrix metalloproteinase," Laboratory Investigation, vol. 79, no. 4, pp. 467-475, 1999.

[111] N. Ramos-DeSimone, E. Hahn-Dantona, J. Sipley, H. Nagase, D. L. French, and J. P. Quigley, "Activation of matrix metalloproteinase-9 (MMP-9) via a converging plasmin/stromelysin-1 cascade enhances tumor cell invasion," The Journal of Biological Chemistry, vol. 274, no. 19, pp.13066-13076, 1999.

[112] T. Sendo, T. Sumimura, Y. Itoh et al., "Involvement of proteinase-activated receptor- 2 in mast cell tryptase-induced barrier dysfunction in bovine aortic endothelial cells," Cellular Signalling, vol. 15, no. 8, pp. 773-781, 2003.

[113] C. J. Meininger, "Mast cells and tumor-associated angiogenesis," Chemical Immunology, vol. 61, no. 1, pp. 239-257, 1995.

[114] L. F. Brown, M. Detmar, K. Claffey et al., "Vascular permeability factor/vascular endothelial growth factor: a multifunctional angiogenic cytokine.", EXS, vol. 79, pp. 233-269, 1997.

[115] A. Friedl, Z. Chang, A. Tierney, and A. C. Rapraeger, "Differential binding of fibroblast growth factor- 2 and -7 to basement membrane heparan sulfate: comparison of normal and abnormal human tissues," The American Journal of Pathology, vol. 150, no. 4, pp. 1443-1455, 1997.

[116] Z. Poltorak, T. Cohen, R. Sivan et al., "VEGF145, a secreted vascular endothelial growth factor isoform that binds to extracellular matrix," The Journal of Biological Chemistry, vol. 272, no. 11, pp. 7151-7158, 1997.

[117] C. S. Karapetis, S. Khambata-Ford, D. J. Jonker et al., "K-ras mutations and benefit from cetuximab in advanced colorectal cancer," The New England Journal of Medicine, vol. 359, no. 17, pp. 1757-1765, 2008.

[118] N. Normanno, S. Tejpar, F. Morgillo, A. de Luca, E. van Cutsem, and F. Ciardiello, "Implications for KRAS status and EGFRtargeted therapies in metastatic CRC," Nature Reviews Clinical Oncology, vol. 6, no. 9, pp. 519-527, 2009.

[119] C. Leporini, F. Saullo, G. Filippelli et al., "Management of dermatologic toxicities associated with monoclonal antibody epidermal growth factor receptor inhibitors: a case review," Journal of Pharmacology \& Pharmacotherapeutics, vol. 4, supplement 1, pp. S78-S85, 2013.

[120] R. Shimamoto, T. Sawada, Y. Uchima et al., "A role for proteaseactivated receptor-2 in pancreatic cancer cell proliferation," International Journal of Oncology, vol. 24, no. 6, pp. 1401-1406, 2004.

[121] V. Ellenrieder, S. F. Hendler, C. Ruhland, W. Boeck, G. Adler, and T. M. Gress, "TGF- $\beta$-induced invasiveness of pancreatic cancer cells is mediated by matrix metalloproteinase- 2 and the urokinase plasminogen activator system," International Journal of Cancer, vol. 93, no. 2, pp. 204-211, 2001.

[122] H. Teraoka, T. Sawada, Y. Yamashita et al., "TGF-betal promotes liver metastasis of pancreatic cancer by modulating the capacity of cellular invasion," International Journal of Oncology, vol. 19, no. 4, pp. 709-715, 2001.

[123] H. Teraoka, T. Sawada, T. Nishihara et al., "Enhanced VEGF production and decreased immunogenicity induced by TGF- $\beta$ 1 promote liver metastasis of pancreatic cancer," British Journal of Cancer, vol. 85, no. 4, pp. 612-617, 2001.

[124] V. Malamud, A. Vaaknin, O. Abramsky et al., "Tryptase activates peripheral blood mononuclear cells causing the synthesis and release of TNF- $\alpha$, IL- 6 and IL-1 $\beta$ : possible relevance to multiple sclerosis," Journal of Neuroimmunology, vol. 138, no. 1-2, pp. 115122, 2003.

[125] L. Woodman, S. Siddiqui, G. Cruse et al., "Mast cells promote airway smooth muscle cell differentiation via autocrine upregulation of TGF- $\beta 1$," The Journal of Immunology, vol. 181, no. 7, pp. 5001-5007, 2008.

[126] X. Zeng, S. Zhang, L. Xu, H. Yang, and S. He, "Activation of protease-activated receptor 2-mediated signaling by mast cell tryptase modulates cytokine production in primary cultured astrocytes," Mediators of Inflammation, vol. 2013, Article ID 140812, 10 pages, 2013.

[127] T. Aoyama, Y. Ino, M. Ozeki et al., "Pharmacological studies of FUT-175, nafamstat mesilate. I. Inhibition of protease activity in in vitro and in vivo experiments," Japanese Journal of Pharmacology, vol. 35, no. 3, pp. 203-227, 1984.

[128] M. Uchiba, K. Okajima, H. Abe, H. Okabe, and K. Takatsuki, "Effect of nafamostat mesilate, a synthetic protease inhibitor, on tissue factor-factor VIIa complex activity," Thrombosis Research, vol. 74, no. 2, pp. 155-161, 1994.

[129] L. B. Schwartz, "Mast cell tryptase: properties and roles in human allergic responses," in Mast Cell Proteases in Immunology 
and Biology, G. M. Caughey, Ed., pp. 9-23, Marcel Dekker, New York, NY, USA, 1995.

[130] J. M. Clark, W. R. Moore, and R. D. Tanaka, “Tryptase inhibitors: a new class of antiinflammatory drugs," Drugs Future, vol. 21, no. 8, pp. 811-816, 1996.

[131] C. P. Sommerhoff, W. Bode, G. Matschiner, A. Bergner, and H. Fritz, "The human mast cell tryptase tetramer: a fascinating riddle solved by structure," Biochimica et Biophysica Acta, vol. 1477, no. 1-2, pp. 75-89, 2000.

[132] T. Yoshikawa, M. Murakami, Y. Furukawa, H. Kato, S. Takemura, and M. Kondo, "Effects of FUT-175, a new synthetic protease inhibitor on endotoxin-induced disseminated intravascular coagulation in rats," Haemostasis, vol. 13, no. 6, pp. 374-378, 1983.

[133] H. Takahashi, S. Takizawa, W. Tatewaki et al., "Nafamostat mesilate (FUT-175) in the treatment of patients with disseminated intravascular coagulation," Thrombosis and Haemostasis, vol. 62, p. 372, 1989.

[134] T. Kimura, S. Fuchimoto, H. Iwagaki, A. Hizuta, and K. Orita, "Inhibitory effect of nafamostat mesilate on metastasis into the livers of mice and on invasion of the extracellular matrix by cancer cells," Journal of International Medical Research, vol. 20, no. 4, pp. 343-352, 1992.

[135] W. Wang, J. L. Abbruzzese, D. B. Evans, L. Larry, K. R. Cleary, and P. J. Chiao, "The nuclear factor- $\kappa$ B RelA transcription factor is constitutively activated in human pancreatic adenocarcinoma cells," Clinical Cancer Research, vol. 5, no. 1, pp. 119-127, 1999.

[136] S. Fujioka, G. M. Sclabas, C. Schmidt et al., "Function of nuclear factor kappaB in pancreatic cancer metastasis," Clinical Cancer Research, vol. 9, no. 1, pp. 346-354, 2003.

[137] A. Arlt and H. Schäfer, "NFאB-dependent chemoresistance in solid tumors," International Journal of Clinical Pharmacology and Therapeutics, vol. 40, no. 8, pp. 336-347, 2002.

[138] C. Rosette, R. B. Roth, P. Oeth et al., "Role of ICAM1 in invasion of human breast cancer cells," Carcinogenesis, vol. 26, no. 5, pp. 943-950, 2005.

[139] S. Huang, J. B. Robinson, A. DeGuzman, C. D. Bucana, and I. J. Fidler, "Blockade of nuclear factor- $\kappa$ b signaling inhibits angiogenesis and tumorigenicity of human ovarian cancer cells by suppressing expression of vascular endothelial growth factor and interleukin 8," Cancer Research, vol. 60, no. 19, pp. 53345339, 2000.

[140] Y. Nagakawa, T. Aoki, K. Kasuya, A. Tsuchida, and Y. Koyanagi, "Histologic features of venous invasion, expression of vascular endothelial growth factor and matrix metalloproteinase- 2 and matrix metalloproteinase-9, and the relation with liver metastasis in pancreatic cancer," Pancreas, vol. 24, no. 2, pp. 169-178, 2002.

[141] W. Wang, J. L. Abbruzzese, D. B. Evans, and P. J. Chiao, "Overexpression of urokinase-type plasminogen activator in pancreatic adenocarcinoma is regulated by constitutively activated RelA," Oncogene, vol. 18, no. 32, pp. 4554-4563, 1999.

[142] T. V. Rakitina, I. A. Vasilevskaya, and P. J. O’Dwyer, “Additive interaction of oxaliplatin and 17-allylamino-17-demethoxygeldanamycin in colon cancer cell lines results from inhibition of nuclear factor $\kappa \mathrm{B}$ signaling," Cancer Research, vol. 63 , no. 24 , pp. 8600-8605, 2003.

[143] C. Wilson, C. Purcell, A. Seaton et al., "Chemotherapyinduced CXC-chemokine/CXC-chemokine receptor signaling in metastatic prostate cancer cells confers resistance to oxaliplatin through potentiation of nuclear factor- $\kappa \mathrm{B}$ transcription and evasion of apoptosis," The Journal of Pharmacology and Experimental Therapeutics, vol. 327, no. 3, pp. 746-759, 2008.

[144] S. Banerjee, A. O. Kaseb, Z. Wang et al., "Antitumor activity of gemcitabine and oxaliplatin is augmented by thymoquinone in pancreatic cancer," Cancer Research, vol. 69, no. 13, pp. 55755583, 2009.

[145] C. Sperti, C. Pasquali, A. Piccoli, and S. Pedrazzoli, "Recurrence after resection for ductal adenocarcinoma of the pancreas," World Journal of Surgery, vol. 21, no. 2, pp. 195-200, 1997.

[146] T. Uwagawa, Z. Li, Z. Chang et al., "Mechanisms of synthetic serine protease inhibitor (FUT-175)-mediated cell death," Cancer, vol. 109, no. 10, pp. 2142-2153, 2007.

[147] K. Furukawa, T. Iida, H. Shiba et al., "Anti-tumor effect by inhibition of NF- $\kappa \mathrm{B}$ activation using nafamostat mesilate for pancreatic cancer in a mouse model," Oncology Reports, vol. 24, no. 4, pp. 843-850, 2010.

[148] T. Uwagawa, T. Misawa, N. Tsutsui et al., "Phase II study of gemcitabine in combination with regional arterial infusion of nafamostat mesilate for advanced pancreatic cancer," American Journal of Clinical Oncology: Cancer Clinical Trials, vol. 36, no. 1, pp. 44-48, 2013.

[149] S. Nystedt, K. Emilsson, C. Wahlestedt, and J. Sundelin, "Molecular cloning of a potential proteinase activated receptor," Proceedings of the National Academy of Sciences of the United States of America, vol. 91, no. 20, pp. 9208-9212, 1994.

[150] S. K. Böhm, W. Kong, D. Brömme et al., "Molecular cloning, expression and potential functions of the human proteinaseactivated receptor-2," Biochemical Journal, vol. 314, no. 3, part 3, pp. 1009-1016, 1996.

[151] A. Kawabata, R. Kuroda, M. Nishida et al., "Proteaseactivated receptor-2 (PAR-2) in the pancreas and parotid gland: immunolocalization and involvement of nitric oxide in the evoked amylase secretion," Life Sciences, vol. 71, no. 20, pp. 24352446, 2002.

[152] V. M. Shpacovitch, T. Brzoska, J. Buddenkotte et al., "Agonists of proteinase-activated receptor 2 induce cytokine release and activation of nuclear transcription factor $\kappa \mathrm{B}$ in human dermal microvascular endothelial cells," Journal of Investigative Dermatology, vol. 118, no. 2, pp. 380-385, 2002.

[153] S. Zhang, X. Zeng, H. Yang, G. Hu, and S. He, "Mast cell tryptase induces microglia activation via protease-activated receptor 2 signaling," Cellular Physiology and Biochemistry, vol. 29, no. 56, pp. 931-940, 2012.

[154] Y. Ma, B. Zhang, R. Qian, C. Lu, F. Zhao, and L. Yin, "Tryptase activates PKB in inflammatory reaction in ECV304 cells," Biochimica et Biophysica Acta-Molecular Cell Research, vol. 1763, no. 3, pp. 313-321, 2006.

[155] W. S. Chen, P.-Z. Xu, K. Gottlob et al., "Growth retardation and increased apoptosis in mice with homozygous disruption of the aktl gene," Genes \& Development, vol. 15, no. 17, pp. 2203-2208, 2001.

[156] M. Cheung and J. R. Testa, "Diverse mechanisms of AKT pathway activation in human malignancy," Current Cancer Drug Targets, vol. 13, no. 3, pp. 234-244, 2013.

[157] S. Kobayashi, T. Asano, and T. Ochiai, "A proposal of notouch isolation technique in pancreatoduodenectomy for periampullary carcinomas," Hepato-Gastroenterology, vol. 48, no. 38, pp. 372-374, 2001.

[158] H. Azuma, K. Banno, and T. Yoshimura, "Pharmacological properties of $\mathrm{N}-\left(3^{\prime}, 4^{\prime}\right.$ dimethoxycinnamoyl) anthranilic acid $\left(\mathrm{N}-5^{\prime}\right)$, a new anti atopic agent," British Journal of Pharmacology, vol. 58 , no. 4, pp. 483-488, 1976. 
[159] H. Komatsu, M. Kojima, N. Tsutsumi et al., "Study of the mechanism of inhibitory action of tranilast on chemical mediator release," Japanese Journal of Pharmacology, vol. 46, no. 1, pp. 4351,1988

[160] M. Isaji, M. Nakajoh, and J. Naito, "Selective inhibition of collagen accumulation by $\mathrm{N}$-(3,4-dimethoxycinnamoyl)anthranilic acid (N-5) in granulation tissue," Biochemical Pharmacology, vol. 36, no. 4, pp. 469-474, 1987.

[161] T. Yanagi, M. Watanabe, S. Fukuda, and Y. Tsuji, "Suppressive effects of tranilast (TN) on human mononuclear cells," Japanese Journal of Inflammation, vol. 7, pp. 169-173, 1987.

[162] H. Suzawa, S. Kikuchi, N. Arai, and A. Koda, "The mechanism involved in the inhibitory action of tranilast on collagen biosynthesis of keloid fibroblasts," Japanese Journal of Pharmacology, vol. 60, no. 2, pp. 91-96, 1992.

[163] M. Yashiro, Y.-S. Chung, and M. Sowa, "Tranilast (N-(3,4dimethoxycinnamoyl) anthranilic acid) down-regulates the growth of scirrhous gastric cancer," Anticancer Research A, vol. 17, no. 2, pp. 895-900, 1997.

[164] H. Shime, M. Kariya, A. Orii et al., "Tranilast inhibits the proliferation of uterine leiomyoma cells in vitro through G1 arrest associated with the induction of p21waf1 and p53," Journal of Clinical Endocrinology and Metabolism, vol. 87, no. 12, pp. 5610-5617, 2002.

[165] M. Rogosnitzky, R. Danks, and E. Kardash, "Therapeutic potential of tranilast, an anti-allergy drug, in proliferative disorders," Anticancer Research, vol. 32, no. 7, pp. 2471-2478, 2012.

[166] D. Padua and J. Massagué, "Roles of TGFbeta in metastasis," Cell Research, vol. 19, no. 1, pp. 89-102, 2009.

[167] K. Izumi, A. Mizokami, T. Shima et al., "Preliminary results of tranilast treatment for patients with advanced castrationresistant prostate cancer," Anticancer Research, vol. 30, no. 7, pp. 3077-3081, 2010.

[168] S. Shigeki, T. Murakami, N. Yata, and Y. Ikuta, "Treatment of keloid and hypertrophic scars by iontophoretic transdermal delivery of tranilast," Scandinavian Journal of Plastic and Reconstructive Surgery and Hand Surgery, vol. 31, no. 2, pp. 151-158, 1997.

[169] M. Isaji, H. Miyata, and Y. Ajisawa, "Tranilast: a new application in the cardiovascular field as an antiproliferative drug," Cardiovascular Drug Reviews, vol. 16, no. 3, pp. 288-299, 1998.

[170] N. I. Kerkvliet, "AHR-mediated immunomodulation: the role of altered gene transcription," Biochemical Pharmacology, vol. 77, no. 4, pp. 746-760, 2009.

[171] A. Gomez-Duran, J. M. Carvajal-Gonzalez, S. Mulero-Navarro, B. Santiago-Josefat, A. Puga, and P. M. Fernandez-Salguero, "Fitting a xenobiotic receptor into cell homeostasis: How the dioxin receptor interacts with TGF $\beta$ signaling," Biochemical Pharmacology, vol. 77, no. 4, pp. 700-712, 2009.

[172] C. E. Ruby, M. Leid, and N. I. Kerkvliet, "2,3,7,8-Tetrachlorodibenzo- $p$-dioxin suppresses tumor necrosis factor- $\alpha$ and antiCD40-induced activation of NF- $\kappa \mathrm{B} /$ Rel in dendritic cells: p50 homodimer activation is not affected," Molecular Pharmacology, vol. 62, no. 3, pp. 722-728, 2002.

[173] M. Ammendola, R. Sacco, G. Sammarco et al., "Correlation between serum tryptase, mast cells positive to tryptase and microvascular density in colo-rectal cancer patients: possible biological-clinical significance," Plos ONE, vol. 9, no. 6, Article ID e99512, 2014.
[174] I. Marech, M. Ammendola, R. Sacco et al., "Serum tryptase, mast cells positive to tryptase and microvascular density evaluation in early breast cancer patients: possible translational significance," BMC Cancer, vol. 14, article 534, 2014.

[175] K. Nanba, T. Oura, S. Soeda, N. Sioya, S. Tsukada, and K. Hanaoka, "Clinical evaluation of tranilast for keloid and hypertrophic scarring. Optimal dose finding study in a double blind study," Nessho, vol. 18, no. 30-45, 1992.

[176] L. K. Ashman and R. Griffith, "Therapeutic targeting of c-KIT in cancer," Expert Opinion on Investigational Drugs, vol. 22, no. 1, pp. 103-115, 2013.

[177] G. Ranieri, M. Mammì, E. Donato Di Paola et al., "Pazopanib a tyrosine kinase inhibitor with strong anti-angiogenetic activity: a new treatment for metastatic soft tissue sarcoma," Critical Review in Oncology/Hematology, vol. 89, no. 2, pp. 322-329, 2014.

[178] E. R. Kessler, D. W. Bowles, T. W. Flaig, E. T. Lam, and A. Jimeno, "Axitinib, a new therapeutic option in renal cell carcinoma," Drugs of Today, vol. 48, no. 10, pp. 633-644, 2012.

[179] I. Marech, R. Patruno, N. Zizzo et al., "Masitinib (AB1010), from canine tumor model to human clinical development: where we are?" Critical Reviews in Oncology/Hematology, vol. 91, no. 1, pp. 98-111, 2014. 

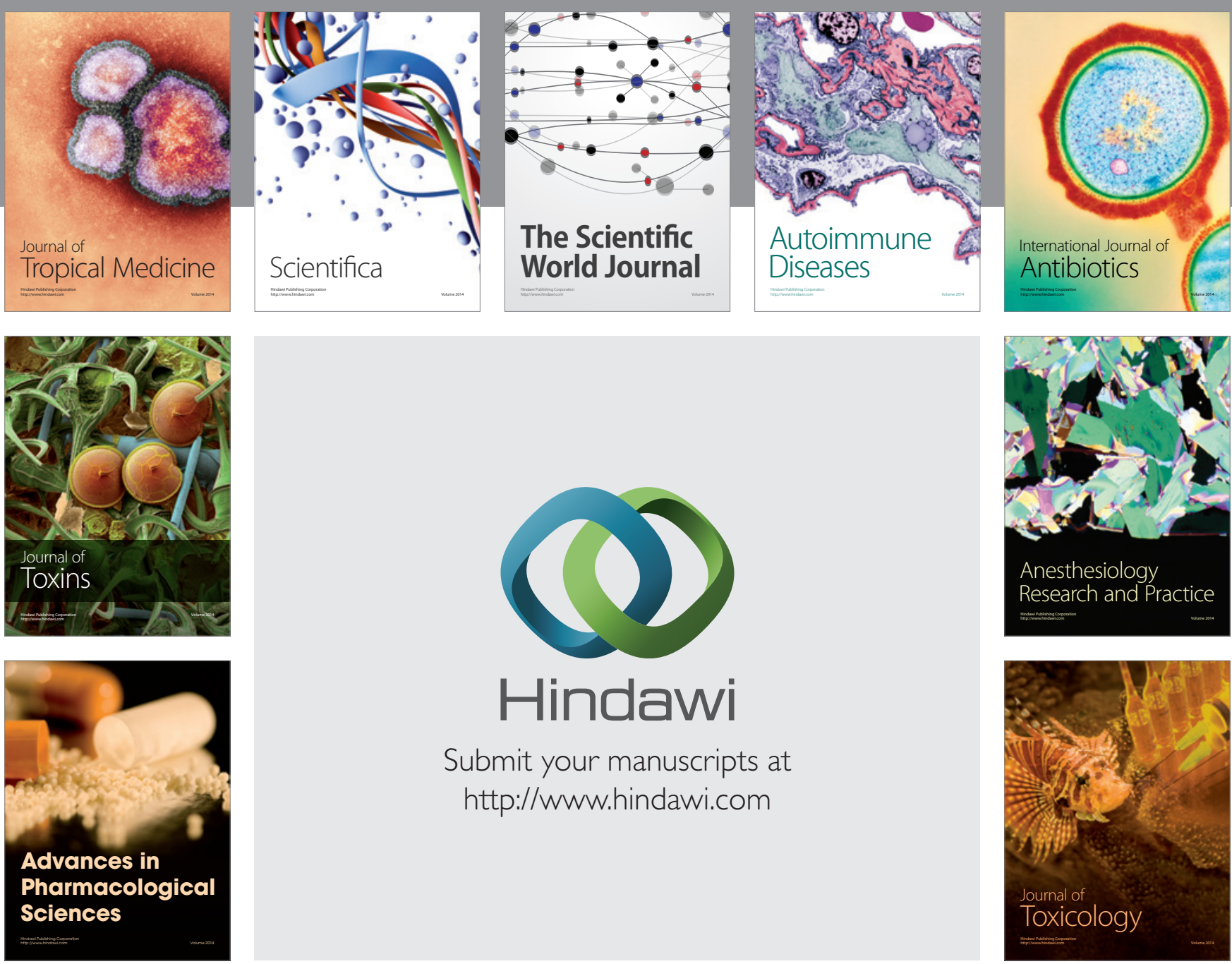

\section{Hindawi}

Submit your manuscripts at

http://www.hindawi.com
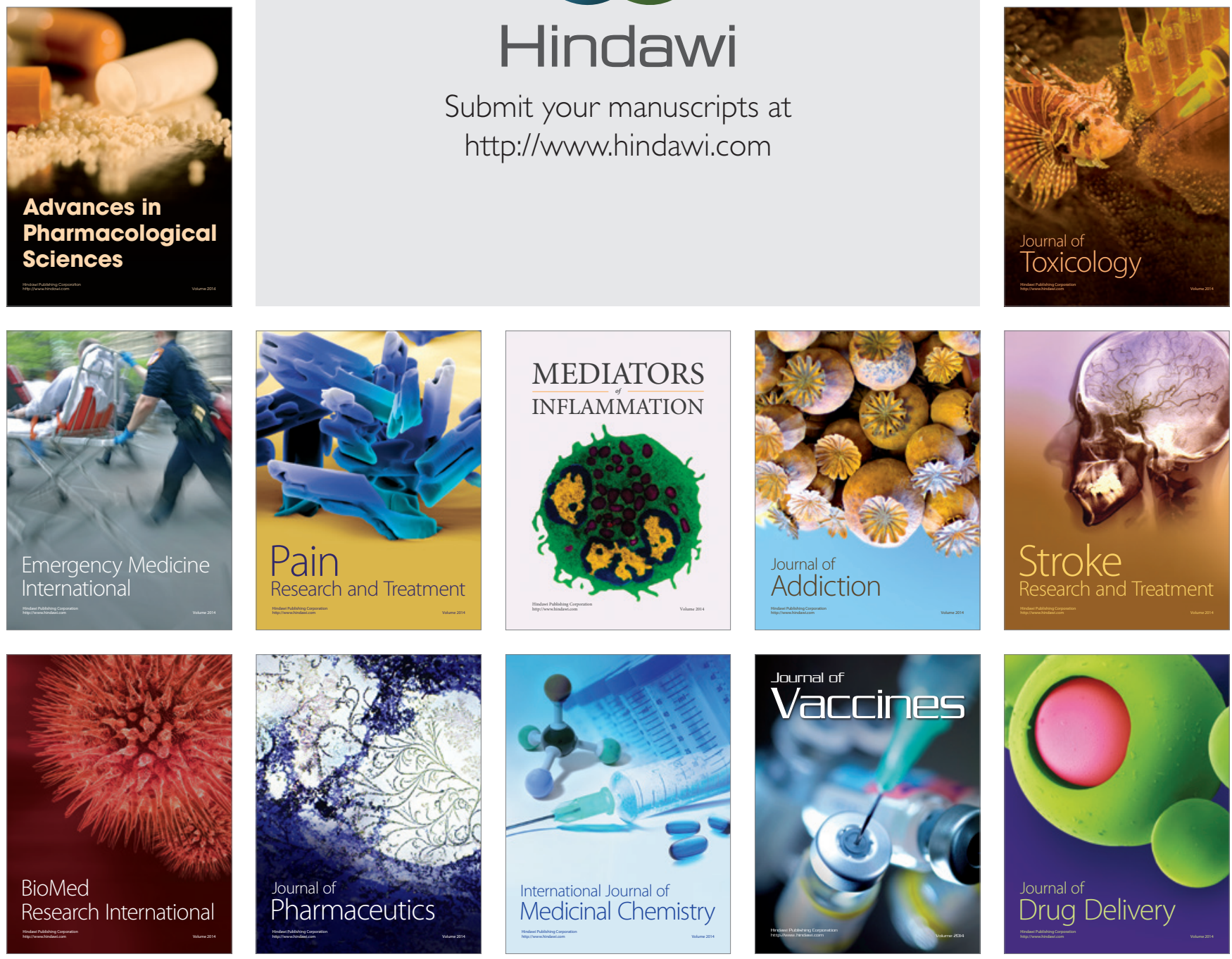